\title{
The Origins and Development of Complex Prehispanic Society in the Lower Santa Valley, Peru: Implications for Theories of State Origins
}

\author{
DAVID J. WILSON \\ Museum of Anthropology, University of Michigan, Ann Arbor, Michigan 48109
}

Received December 15, 1982

\begin{abstract}
A major issue in attempts to construct cross-culturally valid theories of state origins is the relative roles of irrigation agriculture, population growth, and warfare in the rise of complex society. Recently, data from the coast of Peru has provided the stimulus for the formulation of the "coercive theory" of state origins. This theory proposes that state formation in circumscribed environments was the result of population pressure, internecine (local level) warfare, and the incorporation of defeated groups into ever larger, victorious polities. Yet, although the pioneering study of settlement patterns was carried out in Virú Valley, the lack of a comprehensive regional study of the development of prehispanic subsistence-settlement systems in any Peruvian coastal valley meant that the "coercive theory" rested on a precarious data base. Selected results of an extensive and systematic survey carried out in 1979-1980 in the Lower Santa Valley, an area only partly studied prior to our research but long famous for its large number of major prehispanic walls and fortresses, are discussed. Following a discussion of the problem, research methods and data for the early periods leading to state formation are outlined. Analysis of settlement patterns, maize-based carrying capacity, and settlement-cluster ceramic assemblages is then carried out to suggest refutation of the "coercive" model and acceptance of an alternative model of multivariate causality. External, or intervalley, warfare is shown to have been an important socioenvironmental stress leading to sociocultural complexity not only in Santa, but probably in adjacent valleys as well.
\end{abstract}

\section{INTRODUCTION}

During the three decades since publication of the results of the pioneering surface survey carried out in 1946 in Virú Valley (Ford and Willey 1949; Willey 1953), the utility of comprehensive settlement data in understanding the rise of complex irrigation-based society has become apparent to most scholars interested in state origins. Increasingly sophisticated studies of regional settlement patterns have been conducted in other nuclear areas of the world where pristine states arose, most notably in Mesoamerica (Ashmore 1981; Blanton et al. 1982; Bullard 1960; 
Parsons 1971, 1974; Parsons, et al. 1982; Sanders et al. 1979; Willey et al. 1965) and in Mesopotamia (Adams 1962, 1965, 1970, 1981; Adams and Nissen 1972; Johnson 1973; Wright and Johnson 1975).

Researchers in both these areas are now able to outline in some detail how changes through time in the numbers, size, internal complexity, and location of sites correlate with changes in such critical factors as subsistence focus, canal systems, agricultural intensification, population growth and decline, warfare, and levels of sociocultural complexity. At the same time, increasingly complete excavation and settlement pattern data have brought about equally significant advances in the theoretical sophistication with which we view the processes that seem universally to characterize the rise of complex society (e.g., Adams 1966; Flannery 1972, 1976; Peebles and Kus 1977; Price 1982; Sanders and Price 1968; Wright 1978; Wright and Johnson 1975).

However, considering the strong initial impetus provided by the Viru Valley Project for the current revolution in archaeological method and theory, it is surprising to note in recent decades how little the coast of Peru has been a part of the advances outlined above. A case in point is regional settlement patterns. In the first place, viewed in the cold light of current methodological standards used in regional archaeological studies, it is clear that the Virú Valley settlement data are of limited utility to students of state origins since they are neither a complete nor an unbiased sample of extant surface sites (Willey 1953:6). Yet, although a number of settlement pattern studies were carried out on the coast in the 33-year period from 1946 to 1979, none of them, with the exception of Proulx's $(1968,1973)$ Nepeña Valley work, even approached the spatial or temporal scope of the Virú survey (e.g., Bankes 1972; Donnan 1973; Earle 1972; Moseley 1975b; Patterson 1971; Patterson and Lanning 1964; Thompson 1962, 1964; Topic and Topic 1978). ${ }^{1}$ Proulx's study, as mentioned, is a significant exception to the general rule of limited research focus. But, it is fair to say that while it appears to have been more sys-

${ }^{1}$ It should be noted here that over a decade ago Michael Moseley, now of the Field Museum of Natural History, and his associates carried out site surveys over much of the lower $25 \mathrm{~km}$ of the Moche Valley, as part of the Chan Chan-Moche Valley Project. However, since almost none of the data from these surveys are yet available in published form, it is impossible to include any meaningful discussion here on either the nature of the coverage or on early sociocultural development in that area. The single published exception in Bankes' (1972) article on the early ceramic periods, in which a total of three Early Horizon sites and roughly 30 Early Intermediate Period sites are discussed (these latter are rather vaguely assigned to Salinar, Gallinazo, and Moche Periods). In sum, one is forced to conclude that we know essentially nothing about the development of early society in this large and critically important valley, out of which the conquest states of Moche and Chimú are usually assumed to have developed. 
tematic in some respects than the Virú study, it is noncomprehensive and does not consistently provide data on the size, density of occupational debris, or density of structural remains for many of the habitation sites included in the survey (e.g., Proulx 1968:19-24).

Given the lack of comprehensive and systematic regional settlement pattern coverage, it clearly follows that none of the research conducted during the period in question provided us with anything approaching accurate regional estimates of either population numbers in a single period or demographic trends through several periods. Nor are we provided with reliable data on changes in site size and function, site clustering, or major shifts in site location throughout a region over time. It therefore also follows that any theory of the origin of the state which relies for its validity on such incomplete locational and demographic data would at the very least remain open to serious question.

Yet, as is generally well known, a major theory of state origins does indeed owe its initial stimulus and formulation to the prehispanic coastal Peruvian data. I refer to the so-called "coercive theory" of state formation, first proposed by Robert Carneiro over two decades ago (Carneiro 1961), and later presented in developed form in a landmark Science article (Carneiro 1970). Pointing out that Peruvian coastal valleys are classic cases of "environmental circumscription"-i.e., areas of limited irrigable land flanked by sandy desert wasteland-Carneiro goes on to outline what is presumably a "typical" evolutionary sequence leading to state formation in a "typical" coastal valley.

The major details of this presumed sequence are well known, and I shall do no more than point to several critical assumptions of the model that are amenable to field testing. These include (1) an initial stage of dispersed and autonomous farming villages, (2) the rise of within-valley revenge fighting and, later, organized warfare, as population numbers rise against the carrying capacity of the limited land supply, (3) the eventual emergence of village groups organized at the chiefdom level, as the weaker settlements are subjugated by stronger ones, (4) a continuing process of population pressure and within-valley warfare, until the entire region is integrated under one predominant warrior-ruler and the state has emerged; and (5) the rise of between-valley warfare and the eventual formation of multivalley states.

Because of its simplicity and its powerfully persuasive assumption that supravillage organization could never arise through villages voluntarily relinquishing their autonomy, but only through force of arms, Carneiro's theory has received widespread attention in the literature (e.g., Hardesty 1977; Harris 1975, 1977, 1980; Jochim 1981; Service 1975; Wright 1978), as well as reasonably wide acceptance among archaeologists (e.g., Webb 1968; Webster 1975). Yet, prior to the recent research I carried out in 
1979-1980 in the Lower Santa Valley, no attempt had been made to subject the "coercive theory" to a rigorous test within the overall context of an extensive and systematic regional settlement pattern survey.

The Lower Santa Valley in several ways represents an ideal focus for research oriented toward elucidating the relative roles of irrigation agriculture, population growth, and warfare in the rise of complex society. First of all, as with most coastal Peruvian valleys, the Lower Santa region presents a classic example of environmental circumscription (Fig. 1). The Pacific Ocean lies to the west, and arid slopes of the western flank of the Central Andean cordillera rise to over $4000 \mathrm{~m}$ to the east. The lower part of the valley below the confluence of the Tablachaca and Santa Rivers is flanked by rugged desert mountains and sandy pampas, extending $30 \mathrm{~km}$ north to Chao Valley and $45 \mathrm{~km}$ south to Nepeña Valley. Because of the nature of this adjacent terrain as well as the generally narrow configuration of the valley floor, the supply of irrigable land is limited to approximately 11,300 ha (Fig. 2).

Second, Santa is one of the few rivers on the Peruvian littoral that penetrates deeply into the Andean cordillera, and its huge sierra catchment basin supplies more than enough water for irrigation throughout the year. Indeed, at present only about $7 \%$ of the total annual discharge of the river is used for agriculture. Thus, with an average annual air temperalure of $21^{\circ} \mathrm{C}$ and a benign climate year-round, triple-cropping and even quadruple-cropping are possible (ONERN 1972:384ff; Robinson 1971:136). It therefore seems likely that Santa Valley had the potential to support relatively higher numbers of people in prehispanic times than other comparably sized or larger valleys limited by a seasonal water supply.

Third, enough antecedent archaeological work had been done in Santa to have established (1) the rudiments of a ceramic sequence, (2) the presence of ceramic types considered to be major temporal diagnostics in adjacent valleys with better known sequences, and (3) the presence of abundant numbers of defensive structures and walls. Primarily from aerial surveys carried out by Shippee and Johnson (Shippee 1932), and later by Savoy and Sharon (Savoy 1970), it was known that the Lower Santa region contained a large number of impressive hilltop citadels along the rugged desert margin flanking both sides of the valley floor. Shippee and Johnson also discovered from the air a "great wall" running for over 50 $\mathrm{km}$ along the north desert margin. It was presumed to be a defensive wall, and its length made it the longest such feature anywhere in the Americas.

Fourth, the area encompassed within the Lower Santa Valley and adjacent desert margins is small enough to enable a survey team composed at any one time of no more than three to six persons to adequately cover the entire region in a single modestly funded project.

Ultimately, during the course of 14 months of fieldwork in the Lower 


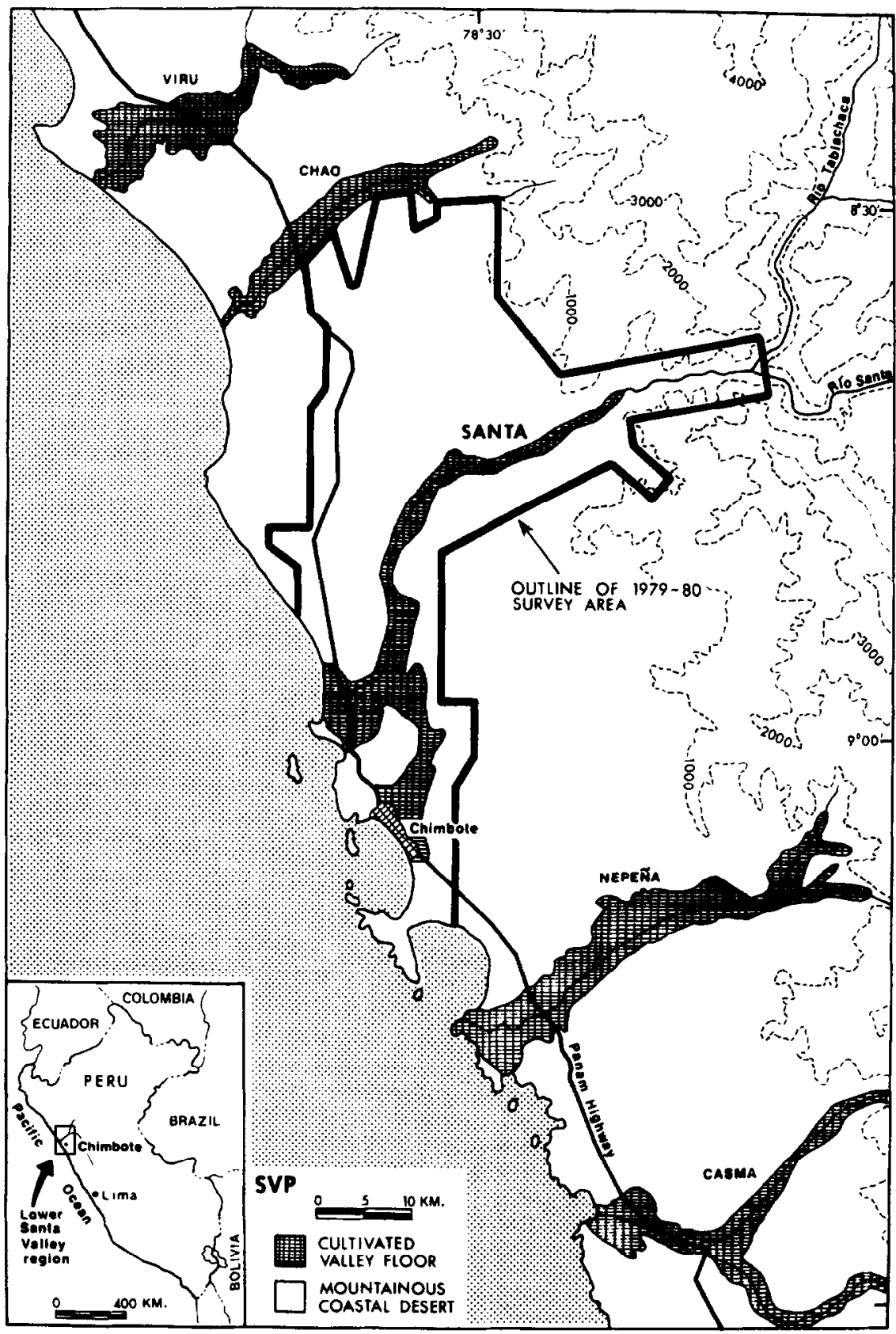

FIG. 1. Lower Santa Valley survey area and adjacent valleys. 


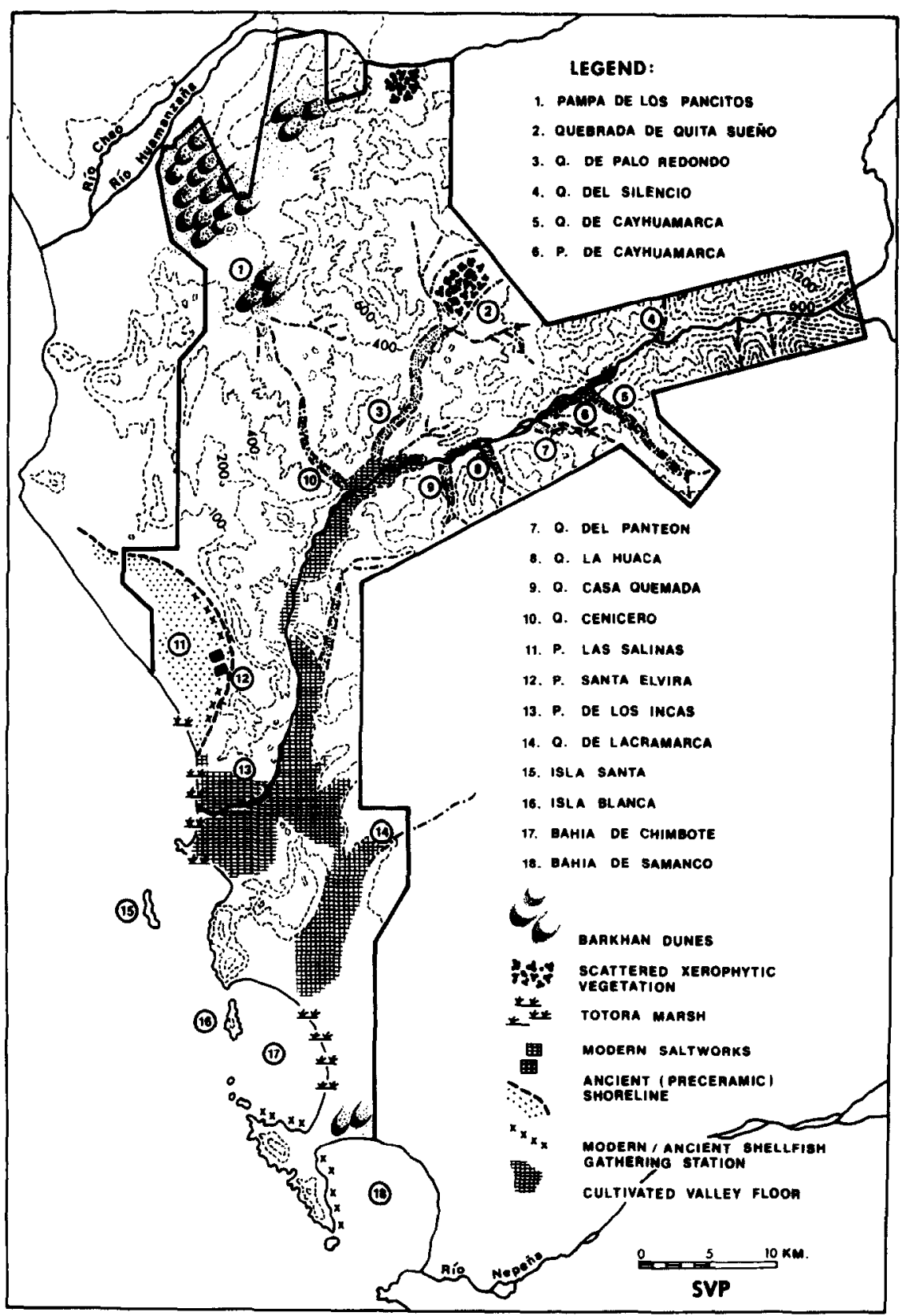

FIG. 2. Major environmental features of the Lower Santa Valley region. 
Santa area, a total of some 1250 sites was found, dating to 10 major periods (Chart 1) from the Preceramic through the Late Horizon (pre1800 B.C. to A.D. 1532). Among the remains mapped in detail were over 60 defensive structures as well as all sections of the "great wall." Judging from associated sites, the wall probably dates to the early part of the Middle Horizon Period (ca. A.D. 650 to 900). Since, as will be discussed briefly in a later section, state formation appears to have occurred before this time-i.e., during the Moche occupation of Santa-I shall not deal further with the wall in this paper, except to note that evidence gathered during the survey strongly suggests that it functioned as an ethnic boundary and not primarily as a defensive construction. However, judging from associated ceramic diagnostics and architectural features, most of the fortresses-or some 57 out of 62 -were built during the four ceramic periods predating the Moche occupation of the valley. It thus seems probable that conflict was an integral part of the formative, or prestate, periods in the Lower Santa region.

Following a discussion of research methods, in the remainder of this paper I will focus on the earlier periods in the sequence, from the Preceramic through the end of Early Intermediate (pre- 1800 B.C. to ca. A.D. 650 ), outlining their principal features and presenting data bearing on the critical roles of irrigation agriculture, population growth, and warfare in the process of sociocultural evolution and the rise of state society. It will be shown that none of the assumptions of Carneiro's model related to within-valley conflict appear to characterize the prestate sequence of Santa. Indeed, the analysis of settlement patterns, maize-based carrying capacity, and ceramic assemblages at the settlement-cluster level suggests that, from the start of irrigation agriculture in the Early Horizon Period (ca. 1000 to 350 B.C.), people were organized at a supravillage level both for subsistence and for defense against raids from outside the valley. Finally, it will be argued that the best approximation of the set of conditions leading to the rise of complex society may be made through use of a model of multivariate causality (cf. Flannery 1972; Wright 1978), and not through a "just so" account based on incomplete data.

\section{RESEARCH METHODS}

In this section principal aspects of the research methods employed during the course of the Santa Valley Project will be discussed briefly in order to provide a meaningful context for the presentation of data on the early periods in the Lower Santa Valley sequence. These aspects include (1) prefield ceramic research, (2) delineation of survey boundaries, (3) definition of subregional environmental sectors, (4) survey methods used, 


\section{CHART 1}

PREHISPANIC PERIODS OF tHE LOWER SANTA VALLEY REGION AND RELATED SEQUENCES

\begin{tabular}{|c|c|c|c|}
\hline $\begin{array}{l}\text { Esfimated } \\
\text { Apsolute } \\
\text { Chronology }\end{array}$ & SANTA VALLEY PERIOD & $\begin{array}{l}\text { Virū Valley } \\
\text { Period }\end{array}$ & $\begin{array}{l}\text { Central Andean } \\
\text { Period }\end{array}$ \\
\hline \multicolumn{4}{|l|}{1532} \\
\hline \multirow[t]{2}{*}{1350} & LATE TAMBO REAL & Estero & Lafe Horizon \\
\hline & EARLY TAMBO DEAL & Lo Plata & Late Intermediate \\
\hline \multicolumn{4}{|l|}{1150} \\
\hline & LATE TANGUCHE & & \\
\hline \multirow[t]{2}{*}{900} & & Tomeval & Middle Horizon \\
\hline & EARLY TANGUCHE & & \\
\hline \multicolumn{4}{|l|}{650} \\
\hline & GUADALUPITO & Huancaco & \\
\hline \multicolumn{4}{|l|}{400} \\
\hline & LATE SUCHIMANCILLO & $\mathbf{L}$ & \\
\hline 200 & & Gallinazo M & Eorly Intermediate \\
\hline A.D & EARLY SUCHIMANCILLO & $\mathbf{E}$ & \\
\hline \multirow[t]{2}{*}{ B.C. } & & & \\
\hline & VINZOS & Puerto Moorin & \\
\hline \multirow[t]{4}{*}{350} & & & \\
\hline & & $\mathbf{L}$ & \\
\hline & CAYHUAMARCA & Guañope & \\
\hline & & $M$ & Early Horizon \\
\hline
\end{tabular}

1000

(?)

E Initial Period

1800 
including ceramic collection procedures, (5) mapping techniques and the derivation of population estimates from surface remains, (6) identifying categories of site function and site size, and (7) delineation of major settlement groupings, or clusters. It may be noted in passing here that one of the major strengths of the reports on the Virú Valley Project was the detailed description of field methods and analytical procedures (see especially Ford and Willey 1949; Willey 1953). Indeed, it is because of this detail that one is able to accurately and fairly assess the Viru research in light of current methods and procedures.

\section{Prefield Ceramic Research}

As is the case in a number of other coastal Peruvian valleys where only studies of limited spatial and temporal scope have been carried out, the better known ceramics prior to our research in Santa were the decorated wares. Little was known about the utilitarian wares which are, of course, essential in any attempt to understand the chronological placement of habitation sites as well as long-term demographic developments. It was therefore considered of critical importance to begin the fieldwork with as complete prior knowledge as possible of all ceramic sequences in the general area, and, as much as possible, to study the ceramics themselves in addition to the published descriptions (major publications on Santa and the adjacent valleys of Moche, Virú, Nepeña, and Casma include Bennett 1950; Collier 1955, 1960; Donnan 1973; Donnan and Mackey 1978; Ford and Willey 1949; Larco Hoyle 1963; Proulx 1968, 1973; Strong and Evans 1952; Tello 1956; Willey 1953).

Nearly complete type collections from Virú Valley, including both utilitarian and decorated wares, were intensively studied and photographed at the Field Museum of Natural History. Other type collections from Virú which were studied include those at the American Museum of Natural History and the Yale Peabody Museum. In addition, at the American Museum, study of a collection of 15,000 sherds made in 1946 by James A. Ford in a 1-week survey of 58 sites throughout Santa Valley provided substantial verification that Virú and Santa shared major ceramic types during most of the prehispanic sequence, including all of the earlier periods. Other ceramics studied in the U.S. include (1) a type collection made by Donald Collier and Donald Thompson in Casma Valley in the 1950s, and presently at the Field Museum, and (2) an extensive series of slides of major Nepeña Valley ceramic types, kindly shown to me by Donald Proulx at the University of Massachusetts-Amherst. In studying these collections from adjacent valleys to the north and south of the research area, it was hypothesized that we could "bracket" our initial 
understanding of the lesser known Santa ceramics with a knowledge of the ceramic types found generally in this area of the North Coast. As we proceeded with the fieldwork in Santa, this hypothesis proved to be valid.

\section{Survey Boundary Delineation}

As shown in Fig. 2, definition of a meaningful survey region was aided substantially by the presence of steep mountain slopes and nearly absolute desert on either side of the narrow valley floor. The upper valley limit of the survey was almost as easily defined since, upstream for some kilometers beyond the confluence of the Tablachaca and Santa Rivers, the canyon is too narrow to permit either irrigation or habitation. Thus, in general, sites of the earlier periods were confined to the area immediately adjacent to the lower $70 \mathrm{~km}$ of the valley floor or to the coastline. It should be noted, however, that in the early part of the Middle Horizon Period an extensive series of rock-lined roads and some 200 associated habitation sites were found extending clear out to the north across the desert to Chao Valley, hence the extension of the survey boundary in that direction. The survey region, as so defined, includes all sites connected in any way with the irrigable portions of the Lower Santa Valley, a 50$\mathrm{km}$ stretch of coastline to the north and south of the valley mouth, and the Santa-Chao desert.

\section{Definition of Subregional Environmental Sectors}

For comparative purposes, such as understanding relative differences in total hectares of available irrigable land and period-by-period population estimates, the length of the valley was divided into Upper, Middle, and Lower Valley sectors, with additional divisions of the survey area including the Coast and Santa-Chao Desert sectors (Fig. 3). The Upper Valley sector is defined as the area of the valley floor and adjacent desert margins between the Tablachaca-Santa confluence and Quebrada La Huaca (see Fig. 2). This sector is roughly $30 \mathrm{~km}$ in length and contains an estimated total of $470 \mathrm{ha}$ of irrigable land, including both the area of modern cultivation ( $280 \mathrm{ha}$ ) and the area adjacent to prehispanic canals (190 ha). The Middle Valley sector is defined as the area of the valley floor and adjacent desert margins between Quebrada La Huaca and the point some $20 \mathrm{~km}$ downriver (northeast of Pampa Santa Elvira) where the valley opens up. This sector contains an estimated total of 1430 ha of irrigable land.

The Lower Valley sector includes the lower $15 \mathrm{~km}$ of the valley, as well as Pampa Las Salinas and the mouth of Quebrada de Lacramarca, areas 


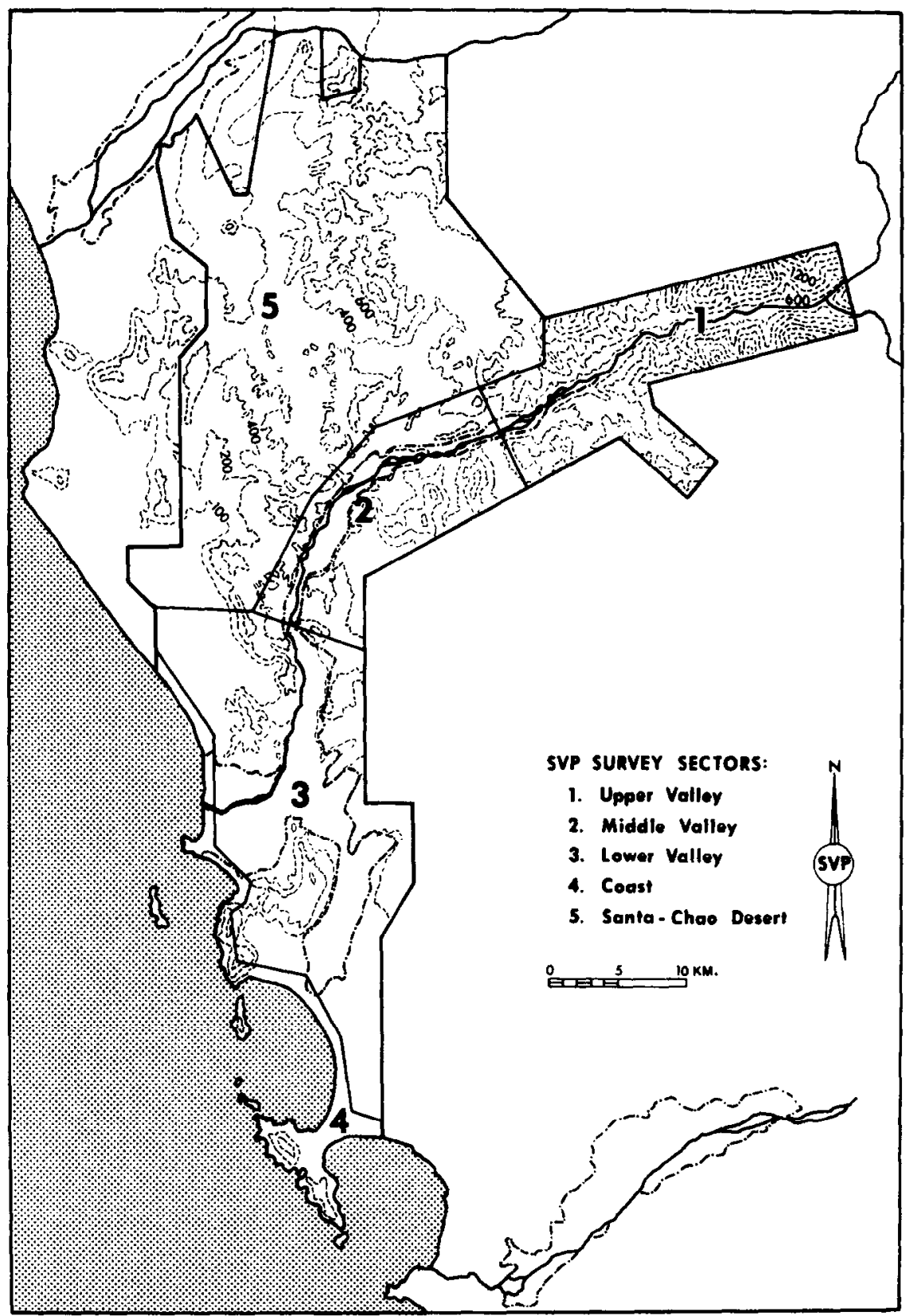

FIG. 3. Survey sectors of the 1979-1980 Santa Valley Project. 
that were cultivated at various times in the prehispanic sequence by canals taken off the Santa River. This sector contains an estimated total of 9405 ha of land suitable for prehispanic cultivation, and ancient canals are found throughout it. The Coast sector is defined as including all prehispanic sites within one kilometer of the ocean. As shown in Fig. 2, although a minimal amount of irrigable land is associated with the Coast sector at the mouth of Santa Valley, everywhere else the land adjacent to the modern (and ancient) shoreline consists of either barren desert or thick totora (Scirpus spp.) marsh. Finally, the Santa-Chao Desert sector includes the remaining northern area of the survey region. Because of the higher rugged terrain immediately adjacent to the north desert margin of Santa and the south desert margin of Chao, all the land within this last sector lies beyond the reach of traditional irrigation technology, which, by definition, is limited to areas that can be reached by contour canals, aqueduct fills, and relatively minor cuts through low, intervening piedmont spurs.

\section{Survey Methods and Ceramic Collection Procedures}

In carrying out systematic reconnaissance and recording of all prehispanic sites in the $750-\mathrm{km}^{2}$ survey area, primary reliance was placed on an extensive series of matte-finish airphotos at scales generally between 1:10,000 and 1:20,000, purchased from the Servicio Aerofotográfico Nacional (SAN) in Lima. For purposes of the fieldwork, an airphoto was taped to a rigid plywood board and the survey team moved in a line across the terrain, recording all prehispanic remains (including habitation sites, fortresses, pyramidal and platform mounds, cemeteries, walls, canals, roads, and data on associated ceramics) directly on the airphoto.

During the course of the survey, no presumptions were made about where sites might and might not be located, and most of the survey region was covered intensively. The single exception to this essentially $100 \%$ surface coverage was the Santa-Chao Desert area, where the network of ancient roads and associated sites is distinctly visible on the airphotos and is confined to quebrada (arroyo) margins, open pampas, and mountain passes. Thus, although a detailed examination was made of the intervening areas of the airphotos, it was unnecessary to cover the steep mountains of the coastal desert here. Elsewhere, as mentioned, all terrain was covered, including both desert margins of the lower $70 \mathrm{~km}$ of the valley.

Over 380 ceramic collections were made throughout the survey region at sites of all periods from the Early Horizon through Late Horizon. These collections were analyzed both in the comparative context of the 
better known sequences of adjacent valleys as well as on a regional, siteto-site basis. Because our sample of collections was from numerous sites of all periods in the survey region, it was possible to identify a number of single-component, or single-period, collections. The resultant chronology (Chart 1) is, of course, provisional until detailed stratigraphic excavations are carried out. However, with extensive survey and substantial numbers of collections, a number of ceramic types were identified for each period that are widely recognized as major temporal diagnostics in the North Coast area.

A related problem to be considered here is the relative length of the various periods in the sequence. As Chart 1 shows, all of the ceramic periods from Vinzos through Late Tambo Real are roughly of the same length. However, the estimated length of Cayhuamarca is about three times that of the later periods. Although the population estimate given for Cayhuamarca later in this paper must therefore be taken as an absolute maximum one, it is also the case that the primary ceramic diagnostics of this period-including the pattern burnished and red polished types-are generally thought to date to the later part of Early Horizon. For example, reporting on pattern burnished sherds found at Guitarrero Cave in the Callejón de Huaylas, Lynch (1980:230) notes that Gary Vescelius assigned them to the Early Huaylas style, which conventionally is dated from 700 to 400 B.C., and the red polished type is assigned by Collier (1955:200) to Late Guanape.

Since the Guitarrero Cave and Virú types are essentially identical to those found in the Lower Santa region, it seems likely that most, if not all, of the Cayhuamarca sites date to the later half of the time period shown in Chart 1. The starting date of ca. 1000 B.C. is therefore somewhat early, but takes into consideration the few sherds found in association with the above types that exhibit presumably earlier characteristics such as unraised circle-and-dot design (Cf. Proulx 1973:22-25; Tello 1956:44). In any case, the length of Cayhuamarca Period is probably not substantially greater than that of the other periods.

Since we were covering a large region and most of the sites encountered had not been studied by previous researchers, the Santa Valley research was in some respects exploratory. The collection procedure could not therefore include a random sampling design. Thus, for example, in the larger sites where sherd debris was extensive and present in denser quantities, collections were made in several sectors at places where it appeared subjectively that a representative sample could be obtained. Here, the collections included all rim sherds of utilitarian and decorated wares, as well as any body sherds with decoration or other potentially diagnostic features. At most sites in the survey area, however, surface diagnostics 
were rather scarce. In these cases, collections had to be taken from the entire area of the site, and included all surface diagnostics that could be found. This was especially the case for the earlier, pre-Guadalupito periods. Still, the number of sherds in each of the 380 collections averaged only 35 , with a range from 10 to as many as 200 sherds per collection.

During the final three months of the fieldwork, full-scale profile and perspective drawings were made of over $60 \%$ of the total of 13,000 sherds collected. In this manner, a complete record was obtained of all major ceramic types and other potentially diagnostic features for later analysis in the U.S.

\section{Mapping Techniques and Derivation of Population Estimates}

Because of the arid climate (the last major rains occurred in 1925) and the generally excellent preservation of prehispanic architecture dating back as far as the Preceramic Period, an important part of the fieldwork involved the preparation of detailed maps at large scale of nearly 150 major structures, fortresses, and habitation sites using either transit-stadia or Brunton-tape. Using these maps, as well as an extensive series of airphoto enlargements of other sites in the survey area obtained at SAN, it has been possible to identify discrete habitation units which, for purposes of estimating population, are assumed to have housed five persons. In addition, four categories of densities of habitation structures are suggested by detailed counts of these habitation units on the site maps and airphoto enlargements. Expressed in terms of persons per hectare ( $p / h a)$, these density categories are (1) low (15 p/ha), (2) low-to-moderate (50 $\mathrm{p} / \mathrm{ha})$, moderate $(100 \mathrm{p} / \mathrm{ha})$, and (4) high (250 p/ha).

Thus, for example, a low density site contains an average of three discrete habitation units per hectare, and, assuming five persons per unit, the population density is 15 persons per hectare. This density category is most characteristic of Preceramic sites and later sites in the SantaChao Desert sector, and it is securely based on actual counts of discrete habitation units made in the field and on the airphotos. The moderate and low-to-moderate density categories are equally securely based since discrete habitation units are reasonably easy to discern, separated by intervening areas where no structures or occupational debris occur. The great majority of sites in all periods along the edges of the valley floor falls into these two categories. The final, or high density, category of 250 persons per hectare is somewhat less securely based since it is difficult to see precisely where one "discrete unit" leaves off and another begins. Nevertheless, while very few sites in the region fall into this category, its existence does allow, for example, a reasonable way of distinguishing 
between low-density Santa-Chao Desert sites and very high-density, terraced habitation sites located on the desert margins adjacent to the valley floor.

Using planimeter estimates of site size and the density categories outlined above, it is thus possible to produce relatively accurate estimates of population for each period, assuming contemporaneity of all sites in that period. Assigning five persons per "discrete habitation unit" is somewhat arbitrary, but consistent and not entirely unreasonable (cf. Haviland 1972; Naroll 1962). In any case, while this method is subject to further refinement as research proceeds, it is considered to be more satisfactory than using only surface sherd densities to estimate population. It must also be emphasized that no assumption is made that the actual numbers of people living in the region are being estimated; rather, taking into consideration differing habitational densities as well as total hectares of habitation in each density category, it allows a roughly accurate means of comparing the total population "potential" of one period to another and of assessing relative population changes over time.

A related problem is the extent to which it can be assumed that a $100 \%$ surface sample of extant prehispanic occupations represents a reasonable approximation of all sites that ever existed in the valley. Obviously, no final judgment can ever be made in this regard, considering all the possible causes of site destruction that may have operated over several thousands of years. For example, the examination of airphoto sets taken several decades apart indicates that the Santa River meanders actively back and forth across some sections of the valley floor. Clearly, then, any prehispanic sites that ever were located on the valley floor near the river are likely to have been destroyed. And, since intensive irrigation has probably brought about some alluvial deposition in cultivated areas, it is not surprising that intensive survey of the valley floor failed to turn up more than a handful of sites.

By contrast, along the margins adjacent to the valley floor we found sites sitting on the desert surface with associated occupational debris dating back to Preceramic and Early Horizon times. Since it almost never rains, there appears to have been no significant erosion or alluvial deposition on the desert surface itself. Thus, as in some areas of the Near East, earlier sites are covered only when occupation continues over many centuries on the same spot. Nevertheless, collections made at several sites of this kind contained as many as six components representing occupation dating back to the earliest ceramic periods. Long-term occupation thus does not seem to have effectively obliterated all traces of earlier remains.

In sum, our sample from the desert margins is likely to be a nearly 
complete one, while the nature of the valley floor sample remains an open question. However, it is probable that no significant occupation ever occurred on the valley floor itself. As mentioned earlier, the supply of land-especially in the Upper and Middle Valley sectors-is so limited that occupation may have been confined from the start of irrigation agriculture to the nonproductive desert margins.

\section{Categories of Site Function}

Another aspect of the methods employed in the Lower Santa research is the approach taken in determining categories of site function. At the most basic level, sites were described in terms of the following functional categories: habitation, cemetery, ceremonial-civic, and defensive.

Habitation sites. A habitation function was inferred in the great majority of cases from the presence of smaller, rock-walled structures, often with associated cultural debris consisting of nonorganic materials (e.g., lithic debitage, grinding stones, utilitarian pottery) and organic materials (e.g., cordage, maize cobs, reed thatching, wood artifacts). Although extensive and occasionally deep midden debris containing these remains was found at a number of sites, associated cultural debris was more often found scattered in lighter densities across the surface, in and around the remains of habitation structures.

Types of dwelling structures include low, rock-walled windbreaks (generally pre-Suchimancillo in date), low rectangular, rock-walled dwellings (dating as early as Cayhuamarca Period), and dwellings built entirely of reed thatching (dating as early as Guadalupito Period, but most characteristic of Early and Late Tambo Real). Habitation settlements were found in a variety of forms, including (1) single, isolated dwellings (very rare), (2) settlements with scattered, or dispersed, dwellings, (3) settlements with agglutinated, or conjoined, dwellings, and (4) settlements on steeper slopes, with dwellings laid out in lines on rock-faced terraces. It is interesting to note that settlements characterized by these dwelling configurations are found in all of the early ceramic periods, from Cayhuamarca on. However, the agglutinated type does not become common until the Early Suchimancillo Period.

Cemeteries. Sites with a burial function were rather easily identified. Indeed, it should be noted that the job of cemetery "identification" has been thoroughly carried out in Santa Valley (and in most other coastal valleys) by the huaquero grave robbers. As is well known to coastal researchers, looted cemeteries are most generally characterized by extensive series of small craters, giving them the appearance from a higher vantage point of having been the object of heavy, pinpoint bombing. The 
cultural debris found associated with these cemeteries usually includes human skeletal and mummified remains, hair, fragments of textiles (funerary shrouds), ceramics (including decorated as well as fire-blackened utilitarian wares), tomb architecture (either of rock or adobe, and frequently very badly damaged), and other organic debris including maize cobs, cotton fragments, and wooden artifacts.

Ceremonial-civic sites. The identification of sites, or parts of sites, as ceremonial-civic was made when one or more of the following architectural features was present: (1) circular sunken courts, (2) pyramidal or platform structures, called huacas, and (3) open plaza areas. All three of these features are characterized by their relatively formal layout and a general lack of evidence that they served as a focus of habitation (a major exception to this latter aspect will be discussed later, in the discussion of data for the Guadalupito Period). Because of these characteristics, as well as the indication (at least in later periods) that corporate labor may have been involved in their construction, all are assumed to have had a special public, or ceremonial-civic, function.

While the first, or circular sunken court, feature is possibly very early on the coast, in the Lower Santa region it is consistently found associated with site groupings dating to Cayhuamarca and Vinzos Periods, in other words, to the Early Horizon and somewhat later. Surface ceramics of both periods were found associated with these features, as well. Smaller pyramidal and platform structures appear to date principally from the Cayhuamarca through the Early Suchimancillo Periods, judging both from associated ceramics and nearby sites. On the other hand, larger adobe structures of truncated pyramidal form-often called castillos-are characteristic of Late Suchimancillo and Guadalupito Periods. The largest adobe huaca structures in the Lower Santa Valley, however, were found to have Guadalupito (Moche) sherds and sites associated with them, and seem clearly to date to that period alone.

With regard to location, all sites and structures classed as ceremonialcivic and dating to the pre-Middle Horizon part of the sequence are located either on the valley floor (both in the midst of cultivated fields and on low hills rising above the floor) or on the immediately adjacent desert margins. All, therefore, are found in accessible and generally quite visible, if not commanding, locations.

Defensive sites. Two principal types of sites were identified as having had a probable defensive function, that is, a function connected with raiding and warfare. The first type consists of citadels, or large rockwalled enclosures that were located primarily on high, usually remote and inaccessible hilltops, often out in the rugged desert terrain as far as 2 to $3 \mathrm{~km}$ away from the irrigated valley floor. In addition to their clearly 
defensible location, citadel sites are characterized by all or most of the following features: higher rock walls (2-4 m), baffled (indirect) entrances, bastions, and one or more defensive ditches. This last feature is found either along relatively gentle access slopes approaching a site or cutting across narrow ridges that approach the immediate vicinity of the structure. In addition, bulwark walls were often used in conjunction with the ditches to reduce ease of access to the citadel. A final important feature of citadels is that almost all were found to have not only evidence of interior habitation (either in the form of utilitarian sherds or smaller structural remains), but also associated habitation sites on the immediate exterior or within several kilometers distance away.

The second type of defensive site is the minor fortress, which usually consists of several smaller, rock-walled structures laid out in a line on a narrow ridgetop or piedmont spur, with one or more defensive ditches and bulwark walls cutting across any gentler ridges that would provide easy access to the site. Minor fortresses are confined entirely to the two Suchimancillo periods, while citadel structures appear to have been built in all four of the pre-Guadalupito ceramic periods.

\section{Categories of Site Size}

The primary criteria kept in mind in selecting settlement size designations were (1) their utility in comparing and contrasting inhabited sites of different size and function in a single period, as well as over time, and (2) personal preference for terms it was felt would reflect reasonably accurately the full range of settlement data collected. As shown in Table 1, the site size categories and population ranges are (1) Hamlet (5-99 persons), (2) Small Village (100-499), (3) Large Village (500-2000+), (4) Local Center (500-3500), and (5) Regional Center $(3500+)$.

The first three site size categories are differentiated primarily on the basis of size, and the population range was determined by visual analysis of site size histograms. The last two categories partly reflect the existence of sites of greater size, but also take into account the presence of public architecture such as major platform structures and open plazas, in addition to large numbers of inhabitants. Most sites in the "Local Center" category have populations ranging between 2000 and 35000 persons, but in the earlier prehispanic periods the presence of substantial remains of public buildings in several sites with populations as small as $\mathbf{5 0 0}$ has made it useful to widen the size range. Although there are at least three periods (Guadalupito, Early Tanguche, and Late Tambo Real) when state society probably existed in the Lower Santa Valley, use of the terms "capital" or "primary center" has been avoided for the largest, most complex sites, and "Regional Center" has been used instead. This reflects the proba- 
TABLE 1

Total Number of Inhabited Sites by Size and Period in the Earlier Part of the Lower Santa Valley Sequence

\begin{tabular}{|c|c|c|c|c|c|}
\hline Period $^{a}$ & 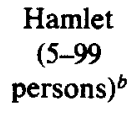 & $\begin{array}{c}\text { Small } \\
\text { village } \\
(100-499)^{b}\end{array}$ & $\begin{array}{c}\text { Large } \\
\text { village } \\
(500-2000+)\end{array}$ & $\begin{array}{c}\text { Local } \\
\text { center } \\
(500-3500)\end{array}$ & $\begin{array}{c}\text { Regional } \\
\text { center } \\
(3500+)\end{array}$ \\
\hline GUAD & 23 & 45 & 5 & 3 & $1^{c}$ \\
\hline LSUCH & 53 & 45 & 7 & 7 & - \\
\hline ESUCH & 54 & 42 & 4 & 3 & - \\
\hline VIN & 21 & 21 & 2 & - & - \\
\hline CAY & 23 & 24 & 2 & - & - \\
\hline SAL & 34 & 2 & - & - & - \\
\hline
\end{tabular}

${ }^{a}$ GUAD $=$ Guadalupito; LSUCH $=$ Late Suchimancillo; ESUCH $=$ Early Suchimancillo; VIN = Vinzos; CAY = Cayhuamarca; $\mathrm{SAL}=$ Las Salinas.

${ }^{b}$ Category includes inhabited citadel sites.

${ }^{c}$ Pampa de los Incas complex (see Fig. 13): eight associated habitation sites.

bility that during these periods Santa was a province of larger, multivalley states whose "primary centers" were located elsewhere.

\section{Delineation of Settlement Clusters}

The final aspect of methods I will discuss is the delineation of major settlement groupings, or site clusters. As examination of the settlement maps included in this paper (Figs. 5, 6, 8, 9, 11, 12) will indicate, almost by definition the distribution of sites in every period shown is "clustered" in the sense that sites are located in essentially linear groupings along either the valley floor or the (ancient) Pacific shoreline. This is, of course, a reflection of the distribution of agricultural and maritime resources. It may be added here that the same pattern characterizes all of the later periods as well. Even during the periods when roads and sites extend out across the desert to Chao Valley, roads are located only where it is "topographically" feasible to locate them, and sites are located only where roads are available to connect them with water, food, and other goods.

However, during the preparation of the larger 1:100,000 scale settlement maps of the 10 periods, it became obvious that most, if not all, of the linear distributions of sites in each period are characterized by subregional clusters, with gaps of $2-5+\mathrm{km}$ between these clusters. Here, it should also be noted that a map was prepared showing the location of all of the $1250+$ sites in the survey region. This map indicates a continuous distribution of sites along the $70 \mathrm{~km}$ of both the north and south desert margins of the valley. In other words, there is no area on either margin 
that, because of environmental or natural features, was unsuitable for occupation. This suggested that the gaps between clusters might be of some significance.

Finally, analysis of a separate set of maps showing the distribution of all ceramic types for each of the periods from Cayhuamarca through Late Suchimancillo indicated that the subregional settlement clusters exhibited not only fundamental similarities with other clusters (e.g., a more or less universal presence of certain utilitarian types), but also a number of differences (e.g., the presence of certain decorated types in only one or several contiguous clusters). ${ }^{2}$ On the other hand, even though subregional settlement clustering is clearly present in Guadalupito (Moche) Period, analysis of the ceramic distribution map for this period showed an essentially continuous distribution of all pottery types throughout the survey region.

In sum, the analysis of settlement and ceramic distribution maps suggested the following: (1) the presence of both site and artifact clustering in the periods from Cayhuamarca through Late Suchimancillo was a potential indication of an orderly, ongoing process, and (2) the lack of clustering of ceramic types in Guadalupito Period might be an indication of fundamental differences between the Moche and pre-Moche periods in the Lower Santa region. Taken as a whole, this part of the analysis raised the possibility that settlement clustering might be indicative not only of adaptation to certain socioenvironmental factors or stresses, but of the presence of subregional socioeconomic or sociopolitical groupings as well.

In view of the above considerations, it seemed useful to delineate the clusters or groupings of settlements in each of the pre-Guadalupito ceramic periods, however tentative these hypothesized groupings might be in terms of their ultimate sociocultural significance. In addition, dealing with subregional groupings of sites in the calculations of maize-based carrying capacity made the delineation of settlement clusters a useful analytical procedure, irrespective of the possibility that these clusters might reflect important aspects of the process of sociocultural adaptation and development.

A final important part of the delineation of clusters was to take into consideration the maps of modern canal locations (see ONERN 1972), as well as our own maps of ancient canal locations. In this manner, separate settlement groupings were made not only with respect to the gaps of 2$5+\mathrm{km}$ between them and the distributions of ceramic types, but also when it seemed clear that the exigencies of irrigation agriculture, canal

\footnotetext{
${ }^{2}$ Intracluster ceramic similarities always included both sides of the river in periods where the sites of a given cluster were so distributed.
} 
technology, and the configuration of the valley floor would have allowed for the possibility of separate canal systems between clusters.

\section{ARCHAEOLOGICAL DATA}

For purposes of this paper, six chronological periods are considered to belong to the earlier part of the Lower Santa Valley sequence. As shown in Chart 1, these periods include Las Salinas, Cayhuamarca, Vinzos, Early Suchimancillo, Late Suchimancillo, and Guadalupito. They span a period of time extending over 2500 years, from the earlier maritime fishinggathering groups organized probably at a tribal level to the later groups organized probably at the level of a multivalley state and focused on irrigation agriculture over large areas of the valley floor.

\section{Las Salinas Period (Cerro Prieto/Preceramic)}

A total of 36 sites probably dating to the later Preceramic, or Las Salinas Period, was found in the survey region (Figs. 4, 5) ${ }^{3}$ All of them appear to be habitation sites, and most cover small areas of about 1 ha or less. Following the general subsistence-settlement pattern of the later Preceramic in other areas of the Peruvian coast, the majority of these sites ( 24 out of 36 , or $66 \%$ ) is located in several clustered groups along the $50 \mathrm{~km}$ of coastline emcompassed within the survey. The 15 shell midden sites of Pampa Las Salinas, which lies to the north of the valley mouth, are situated along an ancient shoreline now located several kilometers inland from the present beach and uplifted to ca. $25 \mathrm{~m}$ elevation by tectonic movement. The former sublittoral area of the Preceramic beach is clearly demarcated by an almost continuous scatter of remains of shellfish and tiny marine crustaceans, stretching in a white belt 50$100 \mathrm{~m}$ wide all around the shoreline.

The 15 shell middens overlooking the ancient shoreline are characterized by the concentrated remains of smaller and larger shellfish, occasional whale vertebrae, and artifactual debris. Fragments of netting and textiles were noted at a few sites, while very light scatters of worked lithic materials exotic to the sandy shoreline area were seen at all 15 sites. No structural remains were noted, so shelters were presumably of a material that has not preserved well. However, habitation structures consisting of low, rock-walled windbreaks were found at all other Las Salinas Period sites, including those farther south along the coast and those lo-

\footnotetext{
${ }^{3}$ The "Key to Settlement Pattern Maps" shown in Fig. 4 has been prepared to cover not only the smaller-scale maps included in this paper, but also a more extensive series of maps at 1:100,000 scale to be included in other publications and the author's dissertation.
} 


\section{KEY TO SETTLEMENT PATTERN MAPS}

PREHISPANIC CULTURAL FEATURES

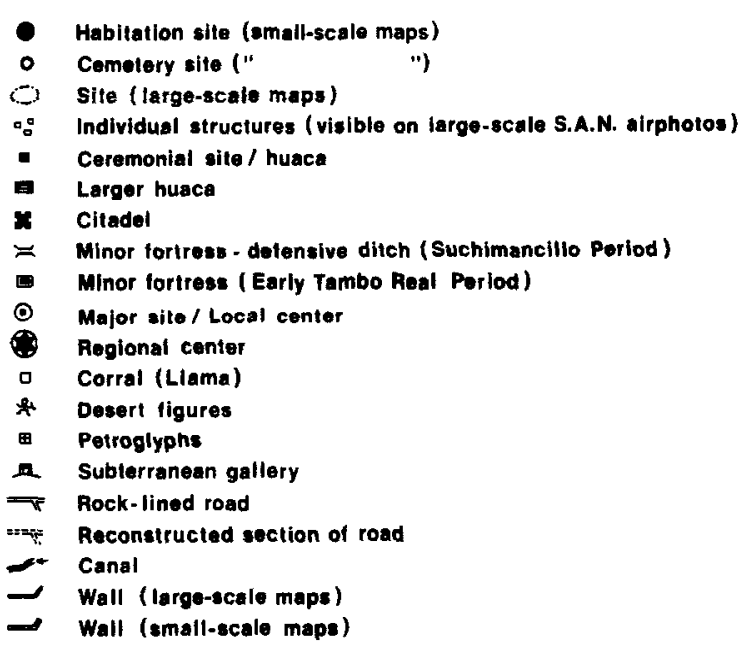

NATUAAL FEATURES

Edge of valley floor

=r. Quebrada

Aiver (large-scale maps)

River (small-scale maps)

thiur Improssionistic contours (based on large-scale airphotos )

- Contour line (based on I.G.M. Hojas 17-f, 17-g, 18-f, 18-g, 19-1)

son Elovation in meters above sea lovel

Caus Hilltop elevation

Wetorral (xorophylic) vegetation

Las Salines (Preceramic) shoreline

FIG. 4. Key to Figs. 5, 6, 8, 9, 11, and 12 .

cated inland in the Middle and Upper Valley sectors. In contrast to many sites of the later, ceramic periods, no surface shell debris was noted at any of the inland sites. The nature of inland subsistence therefore remains unknown, but it is not unlikely that it included hunting-gathering and some form of incipient agriculture. The total population estimate for this period is ca. 1000 persons, assuming contemporaneity of all sites, with an average of 27 persons per site and roughly $60 \%$ of the population located along the coast.

\section{Cayhuamarca Period (GuañapelEarly Horizon)}

The settlement pattern of the succeeding Cayhuamarca Period presents a sharp contrast with the Preceramic. All but 1 of the 54 sites of this 


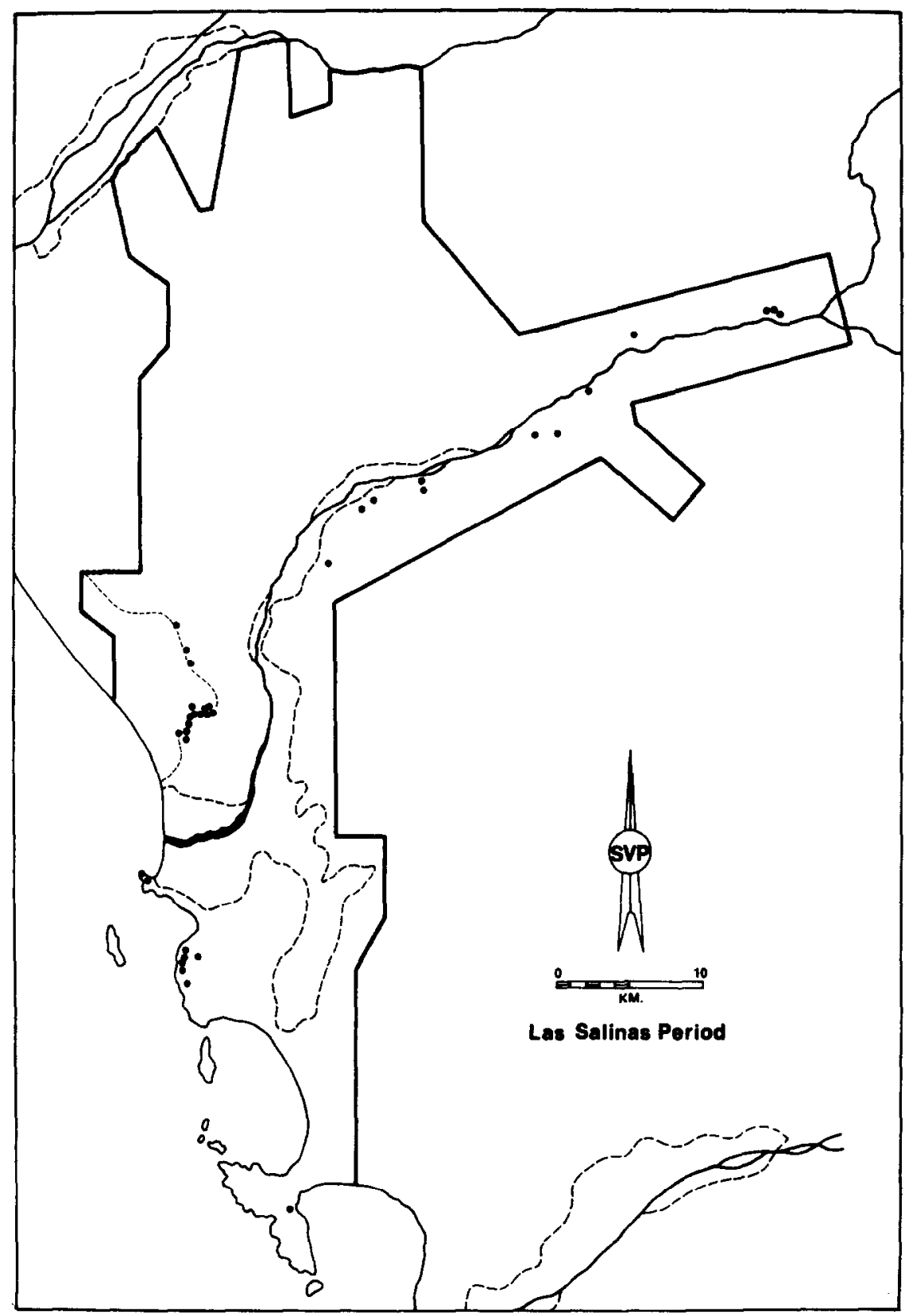

FIG. 5. Settlement pattern of Las Salinas Period. 
period are located in the Middle and Upper Valley (Fig. 6). Settlements are grouped in at least 4 discrete clusters, spaced at intervals of 2 to 4 $\mathrm{km}$ apart, with each cluster containing the same 3 settlement types. These include (1) a number of terraced and nonterraced habitation sites, (2) one to three sites of probable ceremonial-civic function, and (3) one or more large, rock-walled citadels. All but 1 of the 20 citadels dating to Cayhuamarca are located along a $37-\mathrm{km}$ stretch of rugged terrain of the south desert margin, most of them on hilltops or ridges as high as $575 \mathrm{~m}(1885$ ft) above the valley floor.

Structure 33 (Fig. 7) is an example of one of the Cayhuamarca Period citadels. Located on a narrow ridge $200 \mathrm{~m}$ above a cultivated area near Quebrada de Cayhuamarca in the Upper Valley sector, the site consists of massive rock walls with attached buttresses (or bastions) enclosing an area of ca. 2.5 ha. The number of inhabitants is estimated to have been about 125 . To the west and east below the citadel, an extensive ditch of probable defensive function cuts across the ridge and runs for nearly 650 $\mathrm{m}$ along the lower slope to the south. Occupational debris dating to Cayhuamarca and later periods was found in the lower eastern and western sectors inside the enclosure wall, as well as on the highest part of the ridge. Among the Cayhuamarca ceramic diagnostics collected here were the major types characteristic of sites of this period. These include neckless ollas of reddish-brown paste, and red polished and pattern burnished bowls. The red polished type is similar to that found in Viru (cf. Collier 1955:200-202), while the pattern burnished type has essentially identical counterparts in Nepeña (cf. Proulx 1973:23-26), Casma (cf. Tello 1956:46, Fig. 19f), and at Guitarrero Cave (cf. Lynch 1980:230).

As shown in Fig. 6, not all the population of Cayhuamarca Period lived in citadels. However, considering the proximity of all habitation sites to citadel structures, as well as the presence of at least one ceremonialcivic site in each cluster, it seems likely that (1) noncitadel habitation sites relied on nearby citadels during periods of strife (e.g., see Clusters 1 and 4, Fig. 6), and that (2) all citadel and habitation sites relied on nearby ceremonial-civic sites for major religious or other public activities. If this is the case, then it is unlikely that inhabited settlements of this period, whether their primary function be defense or habitation, were "autonomous villages."

The total population estimate for the Cayhuamarca Period is ca. 6000 persons, with an average of 120 persons per inhabited site and 1500 persons per settlement cluster. With regard to subsistence, although sites in the Upper Valley sector are found in association with ancient canals, other nearby sites date to the following Vinzos, and Early and Late Suchimancillo Periods. Thus it is difficult to date the canals precisely as to period, except to say that they are probably no later than Late Suchi- 


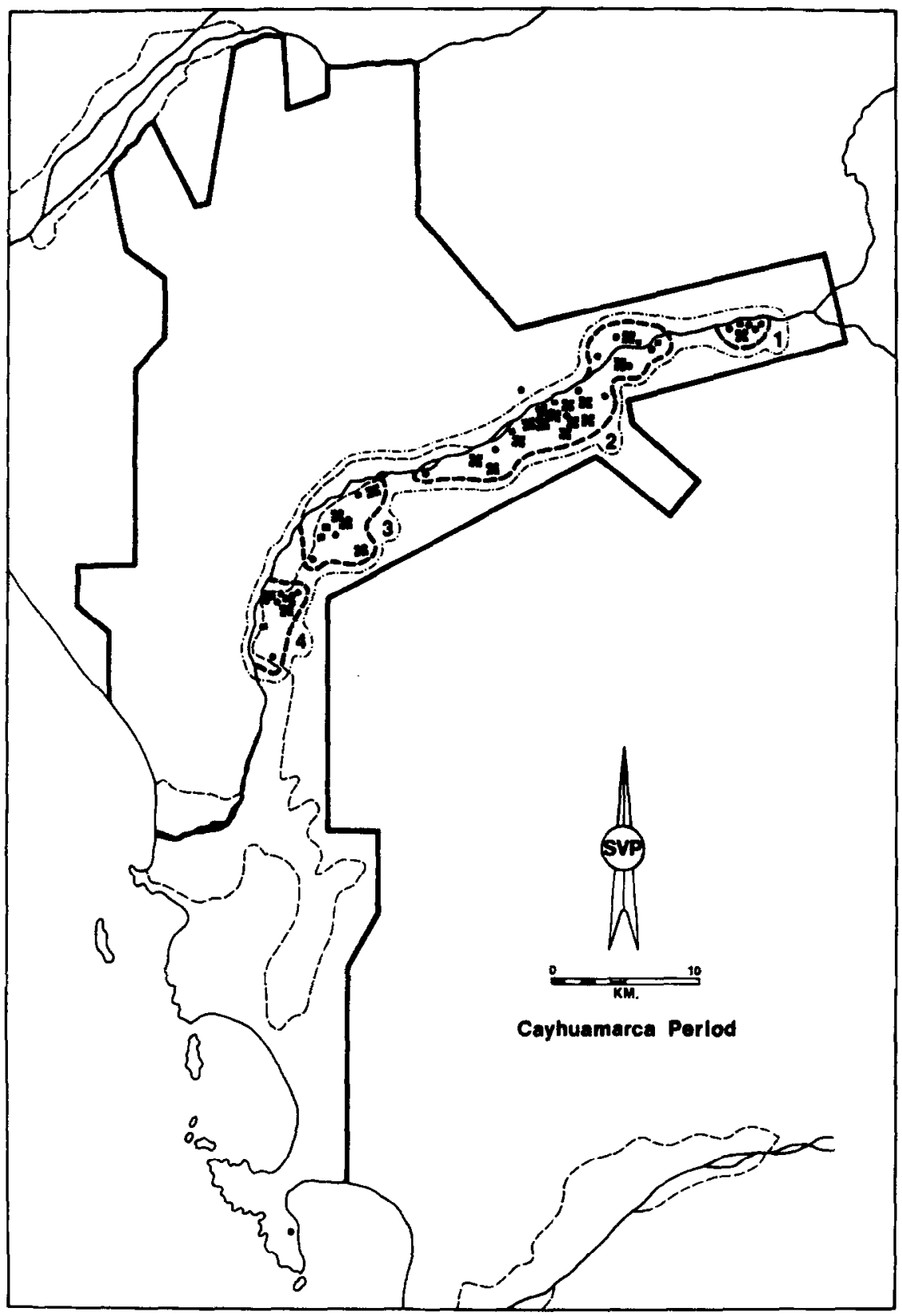

FIG. 6. Settlement pattern of Cayhuamarca Period. 


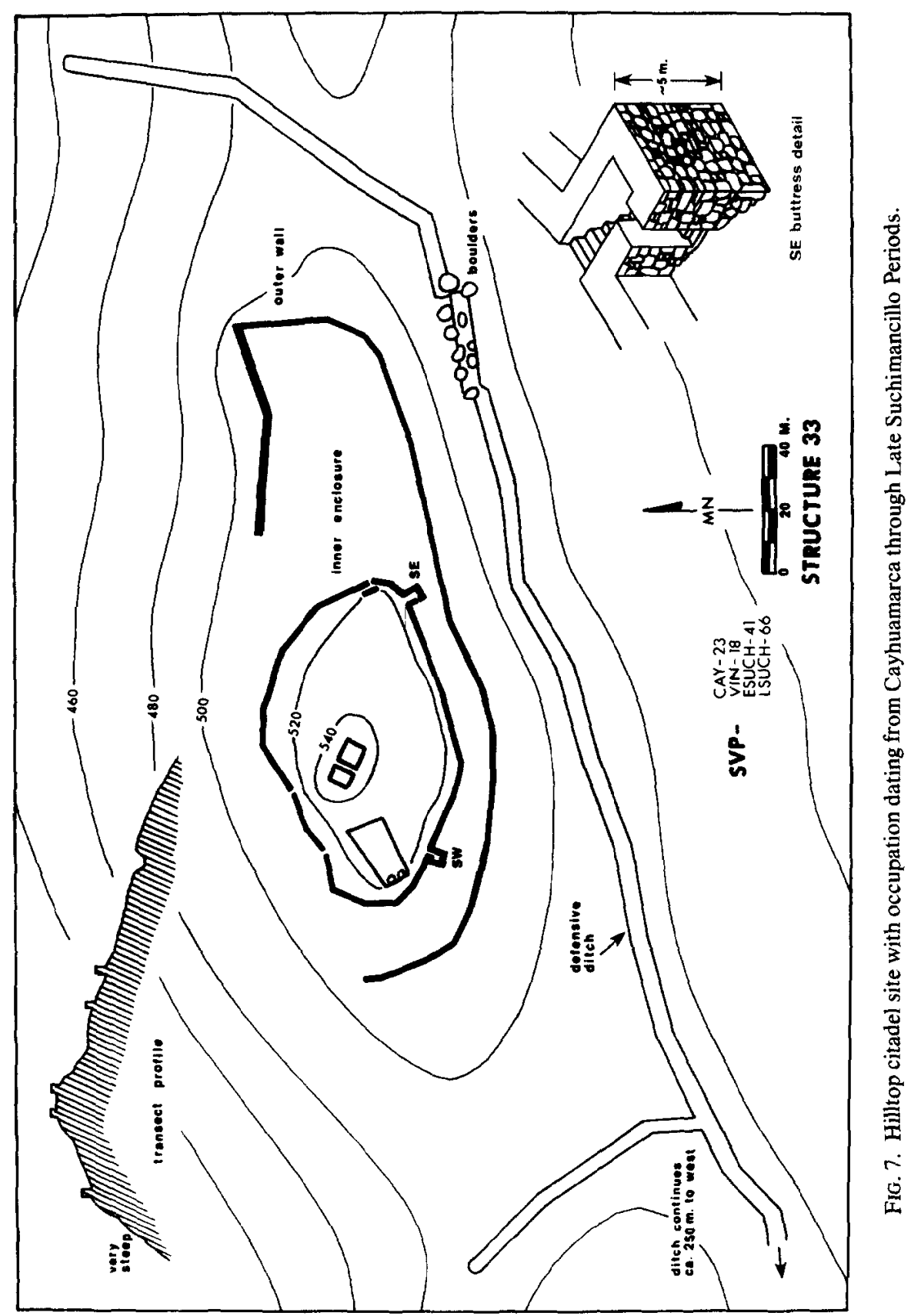


mancillo. The problem of dating canals is even more difficult in the Middle Valley, where sites of all nine ceramic periods are found. However, the results of the maize-based carrying capacity analysis presented later in this paper suggest not only that irrigation agriculture was practiced as early as Cayhuamarca Period, but also that there is no other way populations of $6000+$ persons could have subsisted.

\section{Vinzos Period (Puerto Moorin/Beginning Early Intermediate Period, or EIP)}

The settlement pattern of the following Vinzos Period presents roughly the same configuration as Cayhuamarca Period, although 25 of the 45 total sites are new and there are now 6 settlement clusters. Most of the clusters are similar to those of the preceding period in containing habitation sites, citadels, and sites with public architecture (Fig. 8). The principal ceramic diagnostic of this period is exterior polishing or burnishing marks on vessels with reddish-brown paste, similar both in decorative technique and vessel forms to the Huacapongo Polished Plain vessels of Virú (cf. Strong and Evans 1952:258-261). Vinzos Period ceramics were found associated with only 12 of the 20 hilltop citadels constructed in Cayhuamarca Period. However, with the exception of Cluster 6 and a single large site estimated to have had ca. 2000 inhabitants in Pampa Las Salinas (see Figs. 2, 8), the pattern of locating habitation sites near inhabited fortresses continues from the preceding period. The total population estimate for Vinzos Period is ca. 7850 persons, with an average of 180 persons per site and 1000 persons per cluster.

\section{Early Suchimancillo Period (Early-Middle Gallinazo/Early EIP)}

In the following Early Suchimancillo Period the number of sites in the survey region rises from the 45 of Vinzos Period to a total of 130. Population in the Upper and Middle sectors has doubled, and the first Lower Valley sites appear (Fig. 9). The total population estimate is ca. 20,000 persons, with an average of 200 persons per inhabited site. Three clusters of sites are apparent in the settlement pattern, although the uppermost one (Cluster 1) is obviously of little demographic importance. Nevertheless, because of limited modern occupation, site preservation in this upper part of the survey is excellent. The plan of the eastern sector of SVPESUCH-1 (Fig. 10) is an example of the kind of data that are preserved on these sites and that can be quickly and accurately mapped. The structural remains in the area shown on the plan cover roughly one hectare at moderate densities $(100 \mathrm{p} / \mathrm{ha})$. 


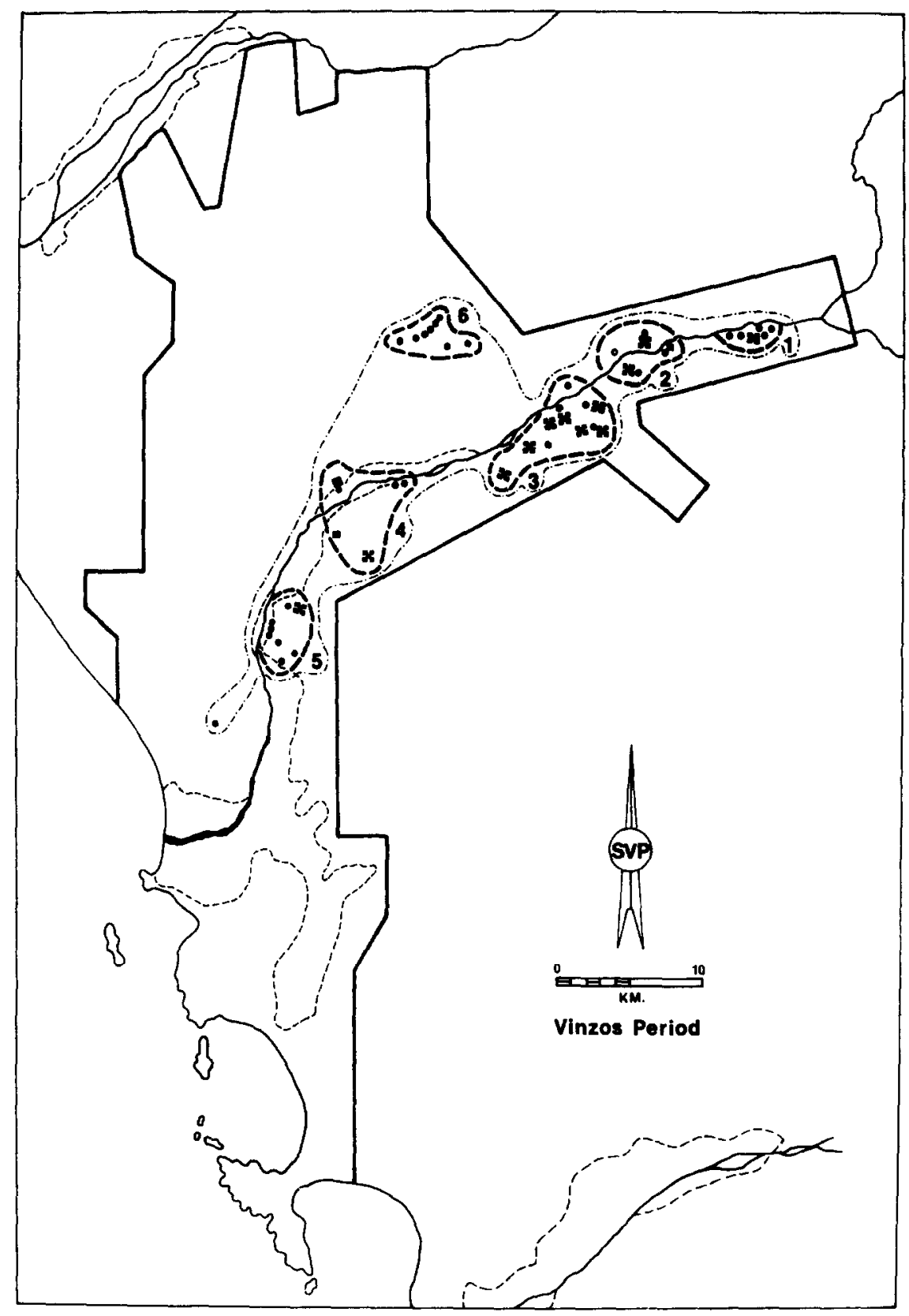

FIG. 8. Settlement pattern of Vinzos Period. 


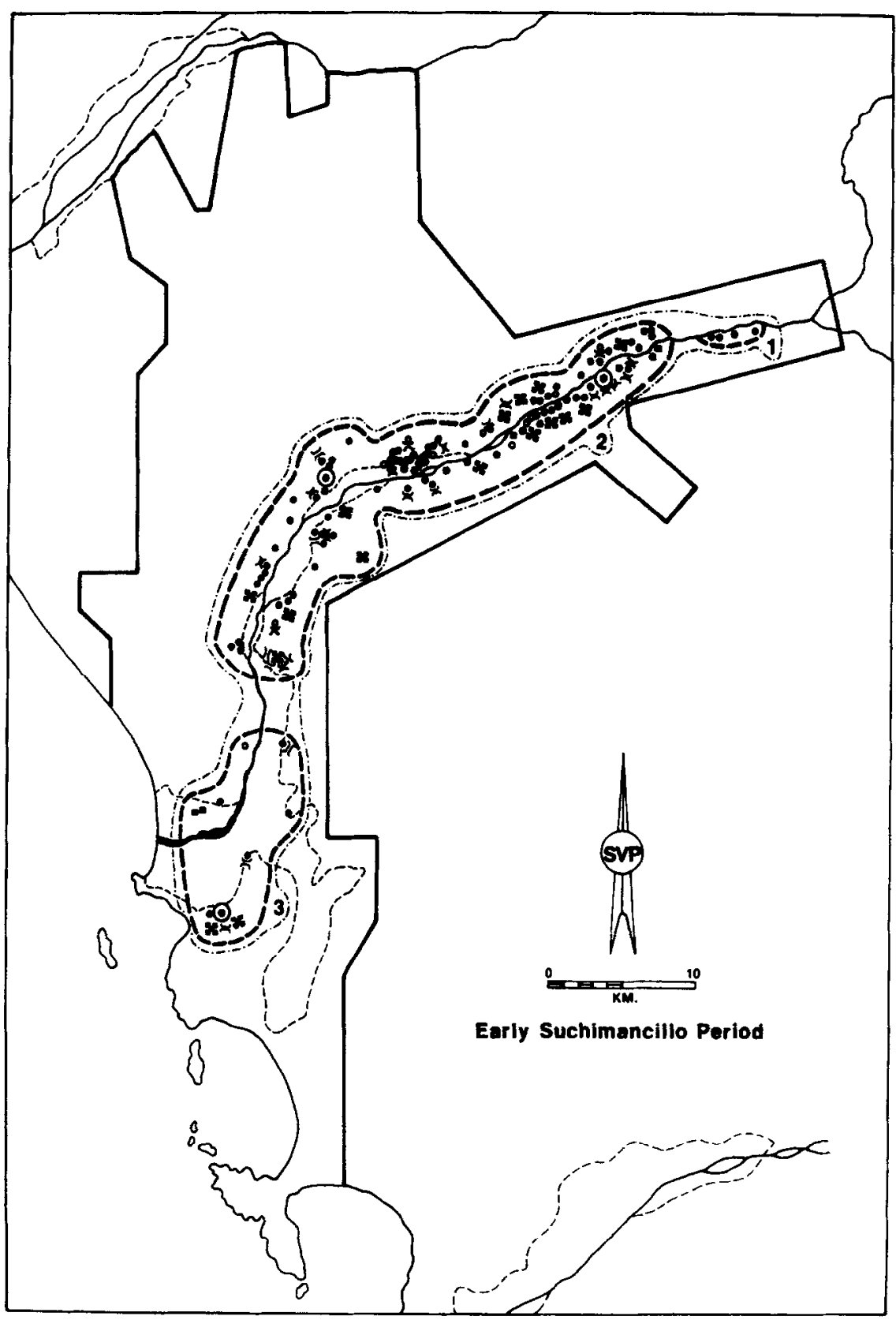

FIG. 9. Settlement pattern of Early Suchimancillo Period. 


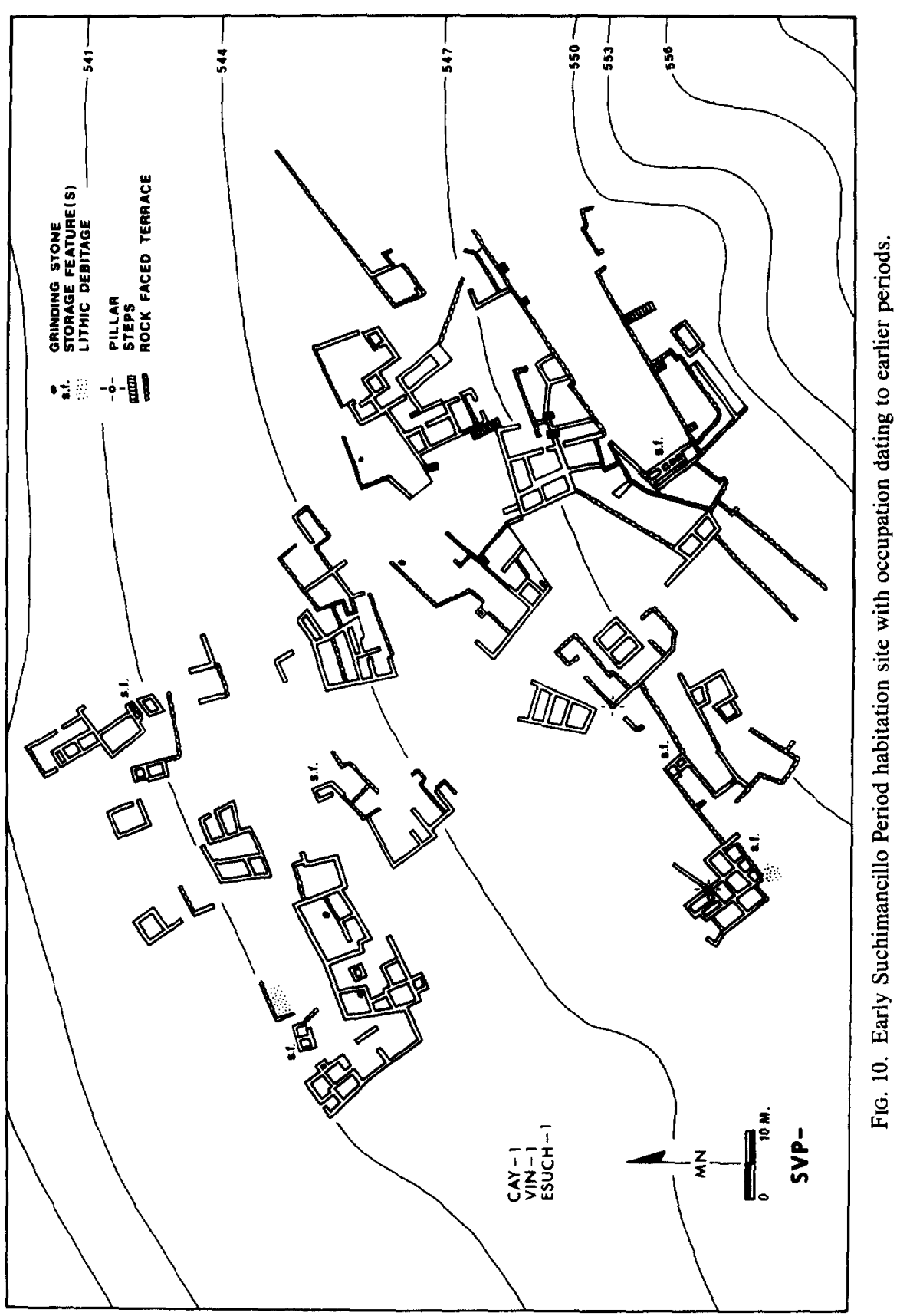


Even though SVP-ESUCH-1 dates back to the beginning of the Christian era, it sits on the desert ground surface untouched by any alluvial debris. Lithic debitage concentrations and several grinding stones in situ, as well as smaller, doorless rooms of probable storage function, are among the remains present at this site that might be thought "unretrievable" by settlement pattern survey and surface mapping. Yet, sites like this can often be found in areas of coastal Peruvian valleys that are remote from present human activities. Indeed, it is appropriate to mention here that the earliest maize (partial cobs, 25-75 mm long) noted on the surface during the fieldwork dates to the Early Suchimancillo Period (e.g., at SVP-ESUCH-87, a terraced habitation site at the western edge of the mouth of Quebrada Palo Redondo).

With regard to other remains, at least two significant features of Early Suchimancillo Clusters 2 and 3 may be mentioned. The first is the increase in the total number of site types. From the three or four of the earlier ceramic periods, the number of site types rises to at least six, including habitation sites, major citadel structures, smaller defensive sites, local centers, ceremonial-civic sites, and cemeteries. Yet, while it appears that society is more complex than in preceding periods-judging both from the increase in site types and from the overall increase in population-it should also be noted that nowhere did we find evidence that Early Suchimancillo groups undertook the kind of monumental construction that characterizes, for example, Guadalupito Period. Both citadels and pyramidal mounds appear to have been constructed during Early Suchimancillo Period, but none is substantially larger than those built in preceding periods.

The second noteworthy feature is the widespread presence of defensive structures in both Clusters 2 and 3, including a total of 40 citadels and minor fortresses (Table 2). As shown in Fig. 9, very few habitation sites

TABLE 2

Total Number of Defensive and Ceremonial Sites in the Earlier Periods of the Lower Santa Valley Sequence

\begin{tabular}{lccccccc}
\hline & \multicolumn{2}{c}{ Defensive } & & \multicolumn{3}{c}{ Ceremonial } \\
\cline { 2 - 3 } \cline { 5 - 7 } Period & $\begin{array}{c}\text { Citadel } \\
\text { (habitation) }\end{array}$ & $\begin{array}{c}\text { Minor } \\
\text { fortress }\end{array}$ & & $\begin{array}{c}\text { Ceremonial } \\
\text { site/huaca }\end{array}$ & $\begin{array}{c}\text { Larger } \\
\text { huaca }\end{array}$ & $\begin{array}{c}\text { Cemetery } \\
\text { site }\end{array}$ \\
\hline GUAD & - & - & & 7 & 6 & 116 \\
LSUCH & 14 & 18 & & 7 & - & 37 \\
ESUCH & 15 & 25 & & 5 & - & 16 \\
VIN & 12 & - & & 3 & - & 1 \\
CAY & 20 & - & & 8 & - & 1 \\
SAL & - & - & & $(1)$ & - & - \\
\hline
\end{tabular}


are located far from a defensive site. It will be recalled that this is essentially the same pattern as that noted for the Cayhuamarca and Vinzos Periods. In addition, it seems clear that, whatever the nature of conflict in the preceding periods, people in the Early Suchimancillo Period were organized at the local level for defense against raids from outside the region. Given the nearly continuous distribution of sites in Cluster 2 and its great numerical superiority compared to Clusters 1 and 3, no other type of warfare can be supported by the data.

However, the ceramic evidence for Early Suchimancillo suggests that patterns of interregional contacts consisted of more than just warfare. For example, several ceramic diagnostics indicate continuing linkage with Virú. Both valleys share the decorated type Castillo White-Red-Orange (cf. Strong and Evans 1952:344-347), as well as several utilitarian vessel forms. In addition, several kaolin bowl types appear. One of these is Black-and-White/Orange, which is found in very similar form at the Balcón de Judás site, at Huaraz in the Callejón de Huaylas (Wegner 1981).

Further evidence of probable contacts between the Lower Santa area and the adjacent sierra is present in a series of desert drawings, discovered during our fieldwork near the modern settlements of Vinzos and Tanguche. Included among these figures, which are similar to those found at Nazca on the South Coast (cf. Reiche 1968a, 1968b), are depictions of 12 llamas and several birds probably representing condors. Although the dating of the figures is tentative, a number of Early Suchimancillo sites are located near both groups, and sherds of this period were the only ones found in direct association with them. In any case, since Early and Late Suchimancillo are the periods when contacts with the sierra seem to have been the strongest-and sierra animals are among the figuresit seems likely they date to one or the other period.

\section{Late Suchimancillo Period (Late Gallinazo/Middle EIP)}

The settlement pattern of the Late Suchimancillo Period is essentially similar to that of the preceding period (Fig. 11). But, while the total number of sites has risen only modestly from 130 to 153 , the overall population of the valley has increased by $50 \%$, from 20,000 to 30,000 persons. This increase is reflected in the change in average site size from 200 persons to ca. 270 persons per inhabited site. In addition, the Upper Valley is now occupied with a nearly continuous distribution of sites on both desert margins, from just above the Tablachaca-Santa confluence to a point downvalley near Quebrada del Panteón. Interestingly, Cluster 1, which contains the least amount of irrigable land (only $380 \mathrm{ha}$ ), has the largest population (ca. 19,000 persons). As will be discussed later, this 


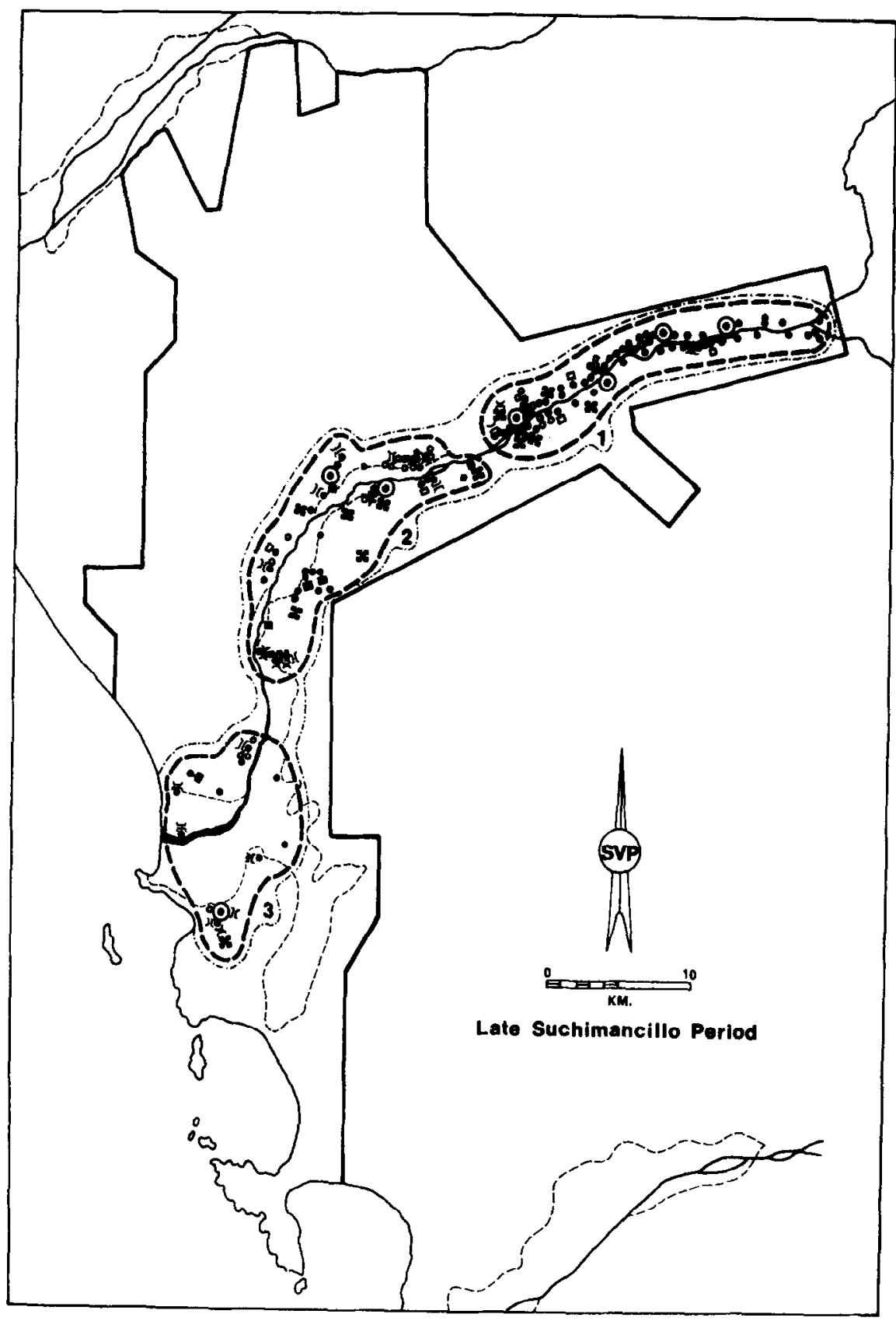

FIG. 11. Settlement pattern of Late Suchimancillo Period. 
has critical significance for understanding not only the nature of intercluster relations, but also the nature of warfare in this period.

Late Suchimancillo Clusters 2 and 3 have the same pattern of widely distributed defensive structures and closely associated habitation sites as in the preceding three periods. The distribution of fortresses in Cluster 1, however, presents an interesting contrast. As shown in Fig. 11, defensive structures are found only in the lower third of this cluster. This is approximately the point where the higher, steeper walls of the Upper Valley canyon open up somewhat, and the hills of the adjacent desert margin become lower and more passable. In addition, several major quebradas provide major access routes into the valley at this point. The distribution of defensive sites throughout Clusters 2 and 3, as well as in the more vulnerable, open areas of Cluster 1 , thus seems to indicate a need for defense against attack from nearby coastal valleys, and not against attack from out of the adjacent sierra.

Indeed, Late Suchimancillo is the period when relations of a presumably peaceful nature between the Lower Santa and the sierra appear to have been more intense than at any other time in the sequence. This also seems to have been the case in nearby Nepeña Valley (Proulx 1973:3035 ), but not in valleys farther to the north and south, such as Virú and Casma. The primary evidence of such contact in the Lower Santa area consists of the widespread distribution of kaolin ware of presumed sierra origin (cf. Bennett 1944; Larco Hoyle 1963). This pottery represents $12.7 \%$ of the Late Suchimancillo material collected during our fieldwork. In comparison, kaolin ware of presumed sierra origin represents only $4.4 \%$ of the collections dating to Early Suchimancillo Period.

It is interesting to note that Late Suchimancillo kaolin pottery was found in the greatest numbers at sites in the lower part of Cluster 1, and throughout most of Cluster 2 . This suggests not only a reasonably strong linkage between Clusters 1 and 2, but also the probability that contacts with the sierra did not occur via the Santa River and the nearly impassable Cañón del Pato area, located some $50 \mathrm{~km}$ farther upstream beyond the Tablachaca-Santa confluence. The most likely primary communication route is the Quebrada de Cayhuamarca, which extends some $15-20 \mathrm{~km}$ to the southeast from the lower part of the Upper Valley sector, and provides relatively easy access to the upper reaches of Quebrada de Lacramarca (and the Callejón de Huaylas) through the rugged, intervening terrain of the main western flank of the cordillera. It should also be noted that it seems highly unlikely that contacts between the Lower Santa region and the Callejón involved anything other than trade (e.g., political alliances). This distance between Late Suchimancillo Cluster 1, for example, and Caraz (at the lower, northern end of the Callejón) via the Quebrada de Cayhuamarca is over $75 \mathrm{~km}$. 
Coupled with the sierra-derived ceramics during Late Suchimancillo is the presence of a number of probable corral features, distributed at ca. $5-\mathrm{km}$ intervals on alternating sides of the river in the Upper and Middle sectors of the valley (Fig. 11). Thus, as was probably the case in the preceding Early Suchimancillo Period, contacts between the Lower Santa and the sierra appear to have involved the use of llamas in transporting goods between the two areas.

\section{Guadalupito (Huancaco/Late EIP)}

The final period to be considered here is Guadalupito, the time of probable Moche occupation of the Lower Santa Valley (cf. Benson 1972; Donnan 1973). Researchers who have dealt with the Moche Period will not be surprised to learn that 116 of the 205 sites we found are cemeteries. However, we also found 84 habitation sites covering a total area of 230 ha, which increases by about 225 ha the total habitation area for the period of Moche occupation discovered prior to our research (cf. Donnan 1973). Average population size of the habitation sites of this period is 260 persons, which represents a slight drop from the 270 persons of Late Suchimancillo. The regional population estimate is 22,000 persons, representing a substantial drop of some 8000 persons from the preceding period. Whether or not this is the result of the Moche incursion into the valley, it is clear from the settlement pattern map (Fig. 12) that a massive shift in subsistence-settlement focus has occurred. While substantial numbers of people live in the Middle Valley, over $80 \%$ of the population is now located in the Lower Valley sector. The population in this latter area is thus over five times greater than the estimate for the preceding Late Suchimancillo Period.

Interestingly, for the first and only time in the prehispanic sequence, the north and south desert margins of Quebrada de Lacramarca are occupied. Judging from sections of ancient canals found along the north margin as well as from the location of modern intakes, the canal serving Lacramarca from the lower part of the Middle Santa Valley was $40 \mathrm{~km}$ long. Other long canals served both the north and south sides of the mouth of Santa Valley. On the north desert margin, for example, extensive remains of prehispanic canals and field lines in the form of serpentine furrows are still excellently preserved at Pampa de los Incas (misnomer), the major center of Guadalupito Period occupation in the valley (Fig. 13). Cultivation and habitation at this complex occurred over an area of some $200 \mathrm{ha}\left(2 \mathrm{~km}^{2}\right)$, and the total population estimate for the eight associated habitation sites is 3500 persons.

In the central part of the Pampa de los Incas complex, two of the largest adobe structures in the Lower Santa region are found (see Structures 19 


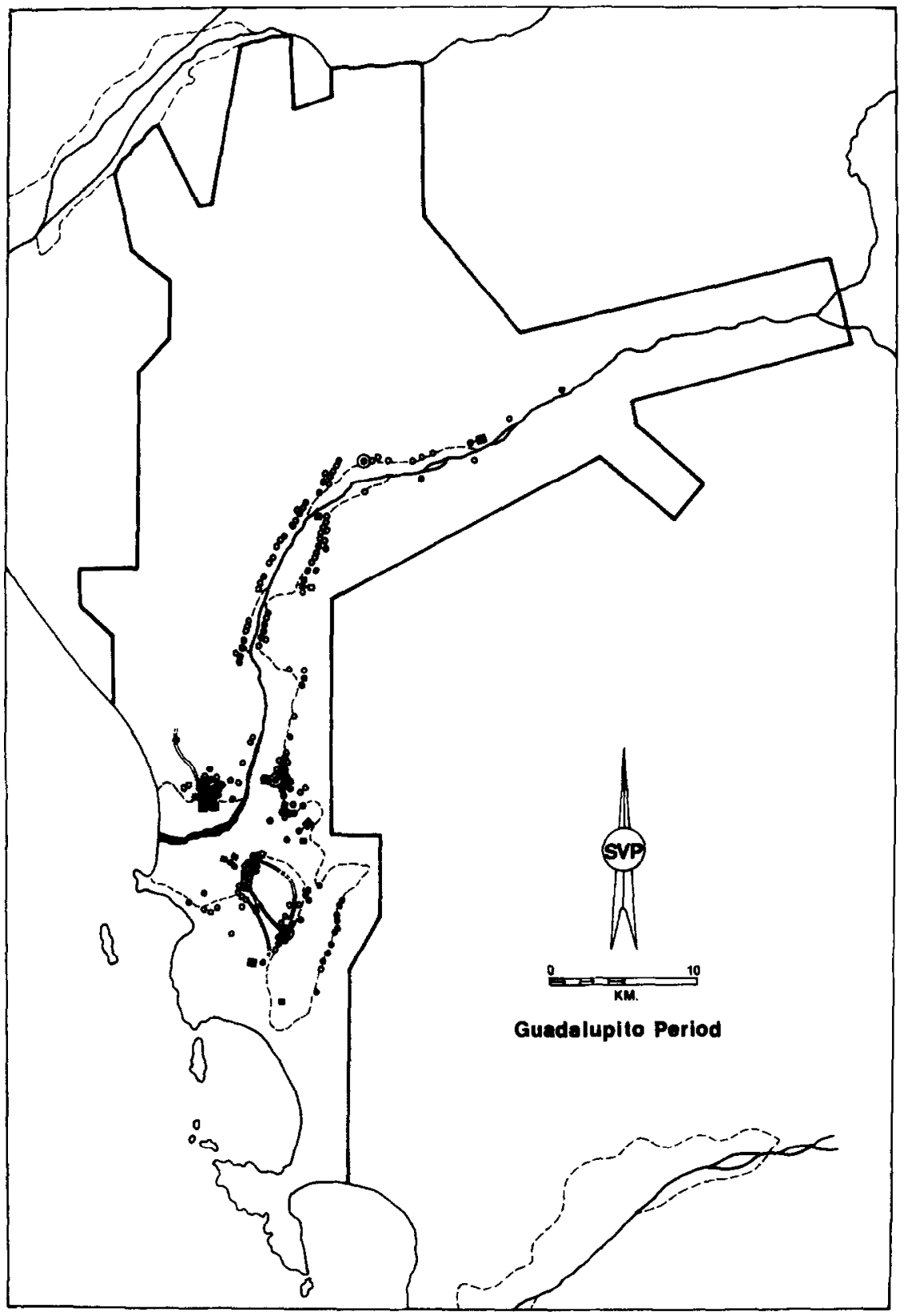

Fig. 12. Settlement Pattern of Guadalupito Period. 
and 20, Fig. 13). Structure 19, the larger of the two platform mounds, measures $135 \times 110 \mathrm{~m}$ in area and stands $16 \mathrm{~m}$ high. Guadalupito habitation debris was found on the top of the mound, as well as on its terraced sides. As shown in the plan view of the complex, a major prehispanic road runs directly up to the north side of the mound. Considering the size and central location of Structure 19, as well as the nature of the entire site, it is likely that it served as the locus of provincial administrative functions for the Moche state and as the residence of the principal regional administrator.

At least five other major platform structures, or huacas, were constructed in the survey region during the period of Moche occupation, including those at Barrio San Pedro (Chimbote), Huaca El Castillo, and Huaca Ursias. The main structure at this last site is an example of one of the best preserved adobe mounds in the region. Located in the middle of cultivated fields near the modern settlement of Tambo Real, Structure 81 measures $110 \times 90 \mathrm{~m}$ in area and stands $11 \mathrm{~m}$ high (Fig. 14). As shown in the perspective view, a massive ramp and several stairways leads up to the top of the structure, where habitation debris, open plaza areas, and intrusive burials of later periods are found.

\section{EARLY INTERMEDIATE PERIOD STATE ORIGINS}

As mentioned earlier, the primary purpose of this paper is to outline the origins of the sociocultural complexity that preceded state formation in the Lower Santa Valley, and to suggest implications for the general developmental sequence in this area of the coast. Nevertheless, it is appropriate at this point briefly to (1) outline working definitions of sociocultural complexity, and of chiefdom and state societies, (2) discuss the data that have been used in the literature to support the assertion that Moche was a multivalley state, and (3) examine selected data from the 1979-1980 Santa Valiey research that bear on the nature of the Moche polity.

\section{Sociocultural Complexity and the State}

The issue of assessing trends in the development of sociocultural complexity is a critically important one, for it centers on one of the major questions that confront archaeologists who investigate the growth of irrigation-based groups in any of the nuclear areas of the world where largescale prehistoric societies arose. Put simply, the question is (1) whether the growth of these early agricultural societies involved merely a quantitative change, i.e., a "proliferation of parts" in an essentially duplicative manner, or (2) whether, as this growth occurred, there was also a 


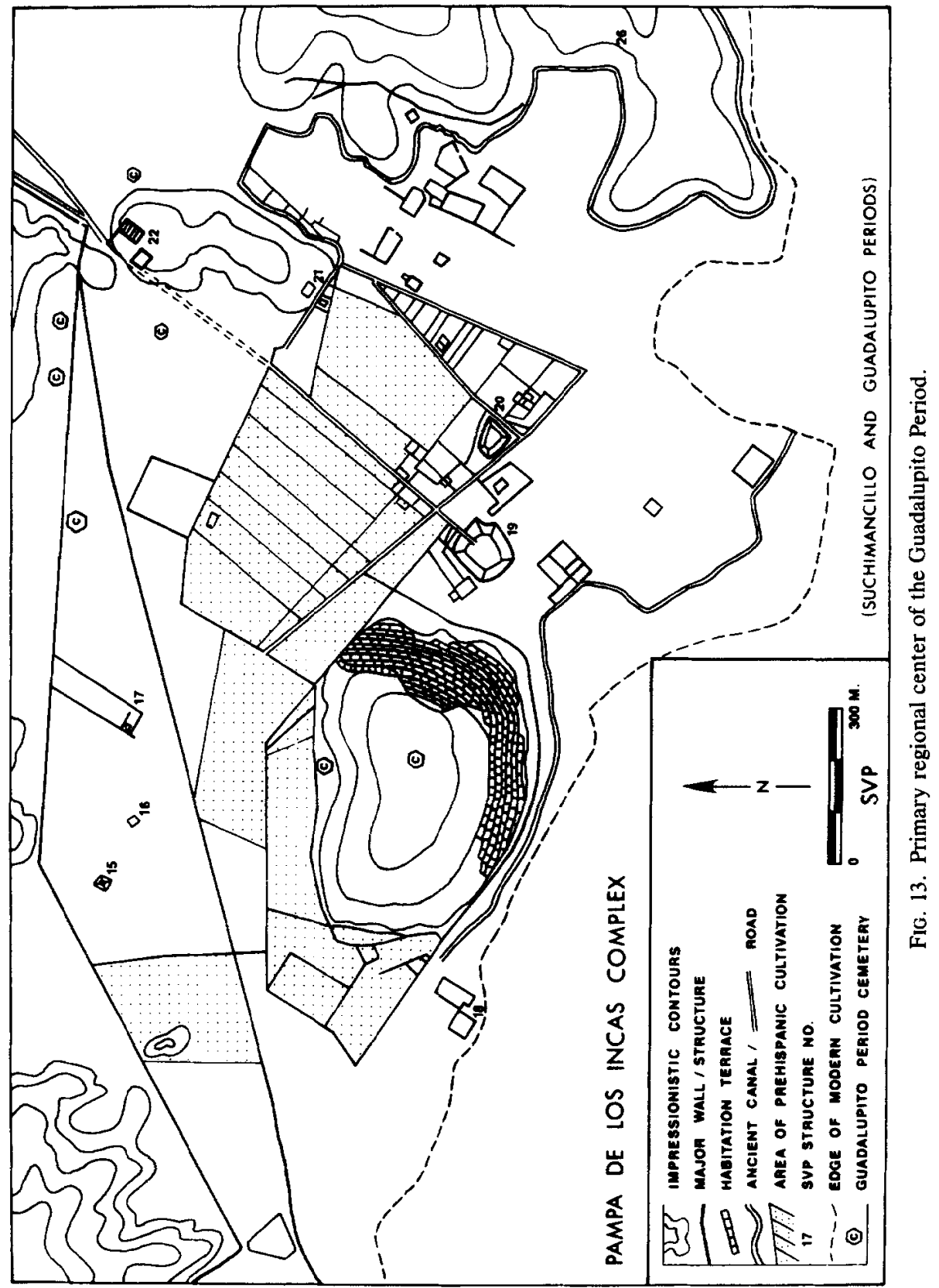



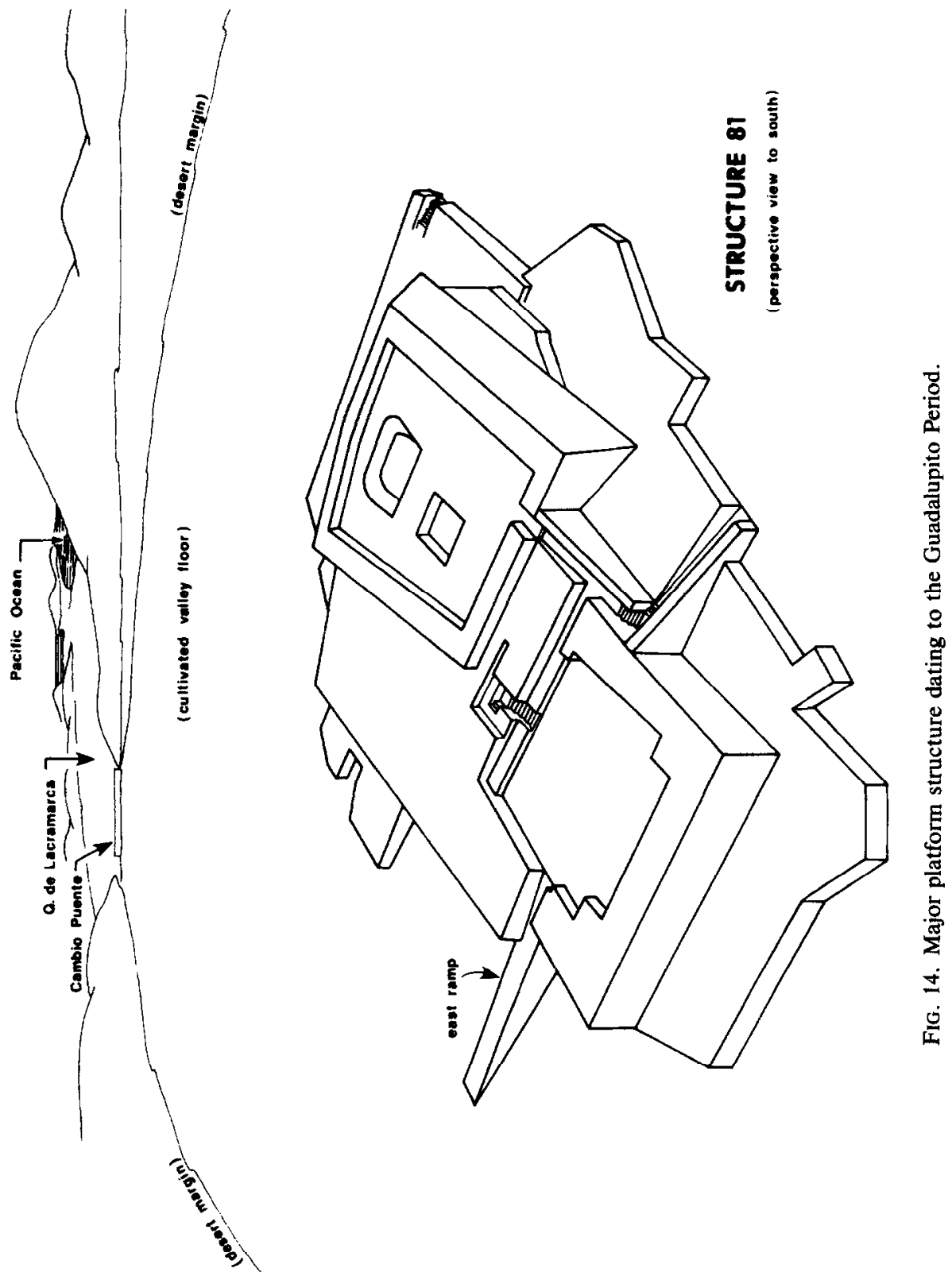
qualitative change in the society, i.e., a proliferation of parts and subparts, such that the society became more and more hierarchically organized.

Given a set of systematically gathered archaeological data from a specific region in one of the nuclear areas, either of these types of growth would, of course, be of potential theoretical interest and importance in understanding sociocultural evolution. Clearly, however, it is the second type that has greater significance, since it would suggest that we are dealing with an orderly process, with important implications for constructing cross-culturally valid, generalizing theories about the origins of complexity and the state.

Assessing sociocultural complexity. As is well known, one of the most cogently argued theoretical statements in the literature dealing with the process of sociocultural evolution is that of Flannery in his 1972 article "The Cultural Evolution of Civilizations." Following a multivariate approach similar to that taken by Adams (1966) and Wright (1978), Flannery has proposed that the evolution of complex sociocultural systems can be understood by reference to the more general aspects of the developmental process itself, rather than by attempting to specify which set of socioenvironmental stresses may have "causal" priority in any given context. Thus, the theory suggests that while all developing sociocultural systems exhibit increasing segregation (or, proliferation of parts and subparts) and centralization (or, increasingly complex control hierarchies), the specification of systemic stresses and their mutual causative relationships is an empirical question to be examined by problem-oriented research.

For purposes of the analysis and discussion carried out in a later section, it is assumed that at least one important measure of increasing sociocultural complexity is an orderly and more or less continuous growth in hierarchies of site size and function. Thus, it is assumed that we are looking at a "classic" case of the development of a complex sociocultural system beyond the level of an egalitarian society if, from the first to the last period in the sequence under consideration (1) there is not only a general quantitative increase in the population (e.g., from 1000 to 30,000 , and then to 22,000 persons in Santa Valley), but also, among other things (2) there is a qualitative change in the hierarchy of site size and function (e.g., from about two to as many as five tiers in Santa).

This latter qualitative change does not imply, however, that for Santa Valley we may automatically assume a state "exists" when a certain number of tiers is present in the hierarchy. Since the number of tiers for any set of settlement data is at least in part a function of the population ranges defining those tiers (see Table 1), we cannot necessarily conclude anything other than that sociocultural complexity is increasing as the number of tiers increases from period to period. 
Even the above conclusion, taken by itself, is clearly an important indication that we are dealing with an orderly process. And if, at certain points in this process, we observe that broad, substantial, or even revolutionary changes have occurred in a developing system, then, whatever we call them (e.g., "ranked society" or "chiefdom"; "stratified society" or "state" or "civilization"), it is equally clear that we are dealing with changes that demand definition and explanation. Elsewhere (Wilson 1981:109-111), following Flannery (1972), Sanders and Price (1968), Service (1975), and Wright and Johnson (1975), I have outlined the principal features of chiefdom and state societies. Here, I will confine the discussion to brief definitions, as well as indicating some of the major "on the ground" features that in the current literature are taken to be diagnostic of these prehistoric ${ }^{4}$ systems.

Chiefdoms. Societies classed as "chiefdoms" are generally viewed as the first to arise beyond the level of egalitarian, or tribal, societies. They appear to have developed in a number of areas of the world, wherever developing food-procurement systems provided a subsistence base that was either capable of substantial intensification or diverse enough to select for higher-order redistributive mechanisms. In either case, the implication is that overall subsistence productivity was relatively higher than that of tribal societies, and, therefore, human population levels numbered in the many thousands or several tens of thousands. By definition, chiefdoms appear to be societies in which the first institutionalized intersettlement socioeconomic and political ties arose, either in response to the need for overall subsistence coordination or to some other adaptive pressure, such as external raiding. As Peebles and Kus (1977:433) have cogently pointed out, one of the key socioenvironmental aspects of the settings where chiefdoms arose is variability or unpredictability, either in subsistence or in overall sociopolitical dynamics.

In addition to relatively larger populations, among the specific characteristics (and archaeological correlates) of chiefdoms are control over a large area (several hundreds of square kilometers), a hierarchy of settlement sizes and functions (two or more levels, or tiers), "chiefly" villages of substantial size (with several thousands of inhabitants), supravillage productive activities (including construction of canals, field systems, public buildings, and fortresses, part-time craft specialization, and interregional trade), and the rise of "chiefly" and "commoner" classes,

\footnotetext{
${ }^{4}$ The use of the term "prehistoric" is intentional here. It indicates my conviction that, while definitions of these systems may benefit significantly from our understanding of the broad systemic and sociocultural features of more recent polities, it is the data from a strictly prehistoric context that ultimately will prove to be more useful in achieving crosscultural understanding and explanation of their evolution.
} 
with status ascribed at birth (and with such differences reflected, for example, in infant mortuary practices).

States. Pristine "civilizations," or "states," are generally viewed as the first societies to arise beyond the level of chiefdom societies. However, while the earliest states in the current fourfold evolutionary schemes are seen as the most advanced level of sociocultural "integration," there are clearly higher levels of complexity that include early empires as well as more recent industrially based nation-states, levels that are characterized by both quantitative and qualitative changes that set them quite apart from their pristine prototypes. The earliest states appear to have developed in a more restricted number of areas (including the Central Andes, Mesoamerica, Mesopotamia, Egypt, the Indus Valley, and China) than did chiefdoms. All of these areas are characterized by arid or semiarid environments where an exogenous water supply and irrigable land provided the critical factors for intensive agriculture, and massive hydraulic and land reclamation works. With a relatively larger subsistence base than chiefdoms, populations numbered at least in the several tens of thousands to as many as several million people. States, by definition, are the first societies in which monopolistic control was exercised over the populace, and, as Flannery (1972:412-413) has suggested, this sort of control may have arisen when earlier institutions in the subsistence-settlement hierarchy were promoted to a higher level.

In addition to substantially larger populations, among the characteristics (and archaeological correlates) of early states are control over a very large area (several hundreds to as many as several thousands of square kilometers); a "fully developed" hierarchy of settlement size and functions (three or more levels, or tiers); primary settlements or urban centers of very substantial size (numbering from at least several thousands to as many as several hundreds of thousands of inhabitants); the rise of legally constituted coercive power or authority, usually based on the existence of a military force (and manifested in such areas as tribute payment, population resettlement, and corporate labor projects, including large hydraulic works and major platform mounds); social stratification (which is reflected in internal diversification of the primary and secondary centers, residence based on occupational specialization and class, and mortuary practices); and full-time craft specialization (again reflected in internally diverse settlements, with certain areas devoted to craft production).

Finally, it may be suggested that, in addition to using the above definitions as a context for understanding major junctures in an evolutionary sequence, it may be of equal importance simply to assess period-to-period settlement pattern maps, looking for times when relatively radical changes occur in settlement types and locations, population size, or other features 
of the archaeological record. It is important to point out, however, that such analytical procedures presuppose that one is dealing with either a complete or a scientifically selected sample of sites in a region.

\section{Evidence for a Multivalley Moche State}

In general, two principal lines of evidence have been used in attempts to argue that Moche was a multivalley state. The first of these relates to the "sudden" and widespread presence of the Moche pottery style in all or most of the valleys from Lambayeque to Nepeña, following the Late Gallinazo Period (e.g., Donnan 1976:2; Strong and Evans 1952:217; Willey 1953:397; see also Proulx 1973:47-49). Among the best stratigraphic evidence attesting to the suddenness of the replacement of Gallinazo decorated ceramic types by those of the Moche style comes from Strong and Evan's excavations at Huaca de la Cruz (V-162) in Virú Valley, where Huancaco (Moche) Period cultural debris was found directly superimposed on that of Gallinazo.

Given the essential similarity of Huancaco ceramics to those of Moche Valley, as well as the pervasive theme of militarism in Moche iconography (including scenes of battles between warriors of different dress and, presumably, cultural backgrounds; cf. Donnan 1978:35-36, 45-51), Strong and Evans argued that Virú had probably been incorporated by direct conquest into a multivalley state. And, as the Virú settlement data indicated (Ford and Willey 1949:65-66; Willey 1953:178-234, 397), the replacement of Gallinazo types by pottery of the Moche style occurred everywhere in the valley.

The second major line of evidence relates to the appearance of monumental architecture-with associated Moche cultural diagnostics, including pottery and murals-in all or most of the valleys that were presumably incorporated into the state (Lumbreras 1974:99-100). Among the best known of the provincial monuments is the large complex of Panamarca, which covers an area of ca. $200 \times 150 \mathrm{~m}$ in the lower Nepeña Valley (Proulx 1968:78-80). Although sections of the site were probably built before and after the Moche Period, it is also clear that the primary use of the site and most of its construction (including a large $40 \times 40 \mathrm{~m}$ pyramidal structure) occurred during the period of Moche occupation. The majority of surface ceramics at the site date to this period, and Pañamarca is well known for a series of large polychrome murals done in the Moche style. Included in these murals (now mostly destroyed) are depictions of (1) warriors in hand-to-hand combat (cf. Bonavia 1974:6063; Schaedel 1951), and (2) probable ceremonial-civic activities that Donnan (1976:117ff) has called the "Presentation Theme," a theme which 
also appears on Moche pottery vessels of (apparently) various proveniences.

By far the largest monumental constructions anywhere in the area of Moche influence, however, are those of the Huaca del Sol and Huaca de la Luna, located at a large site covering $2+\mathrm{km}^{2}$ along the south desert margin of the Moche Valley, a few kilometers inland from the ocean. Considering its size and potential importance, the site of Moche has been the object of surprisingly little scientific research and publication (for notable exceptions, see Hastings and Moseley 1975; Moseley 1975a). However, notwithstanding the fact that much more work needs to be done at Moche, especially in terms of accurately assessing its size and the nature of occupation away from the huacas themselves, it seems clear that this site represents the best candidate for the primary center of the Moche state.

\section{Santa Valley as a Province of the Moche State}

Three related sets of data are available from the 1979-1980 research in Santa Valley that bear on the nature of the spread of Moche culture, including monumental architecture, settlement patterns, and ceramics. All three sets of data, I believe, not only provide strong indication that Santa became part of a multivalley polity during the last part of the Early Intermediate Period, but also provide important verification that such a polity indeed existed. Having already discussed the first two sets of data in the section on Guadalupito Period, I will only briefly touch on them here before discussing the ceramic evidence.

As shown in Table 2, Guadalupito is the first (and, interestingly, the last) period in the Lower Santa sequence when relatively larger platform mounds of presumably ceremonial and elite habitation function were built. All but one of these mounds are located in or very near the three major population concentrations of Pampa de los Incas, El Castillo (to the east, across the river from Pampa de los Incas), and the mouth of Quebrada de Lacramarca. During the mapping of El Castillo site, we discovered (and prepared a drawing of) a polychrome mural on the northern face of Structure 88, the lower one of the two major pyramidal structures on the site. The mural depicts at least four club-and-shield motifs, laid out in a line along with two additional shield motifs. It seems possible that this mural and the militaristic scenes in the Pañamarca murals represent a formal expression of the Moche conquest of Santa and Nepeña Valleys.

Of equal interest is that, during our study and mapping at Pampa de los Incas complex, an adobe with a probable maker's mark (consisting of an incised rectangle with an " $\mathrm{X}$ " inside it) was noted on the summit 
of Structure 19, the principal Guadalupito Period huaca in the Lower Santa region, as discussed earlier. Although no other adobes with maker's marks could be found, this provides some evidence that the principles of corporate labor organization and monument construction adduced by Moseley (1975a) for Huaca del Sol and Huaca de la Luna at Moche were also a feature of the construction of provincial platform structures.

Aside from the pronounced change in settlement patterns from Late Suchimancillo to Guadalupito Period-consisting, as mentioned in the preceding section, of a massive shift in population focus from the Upper to the Lower Valley sector-the ceramic evidence provides additional strong support for the hypothesis of a Moche conquest of Santa and incorporation into a multivalley state. As opposed to the preceding Late Suchimancillo Period, when ceramics show only partial similarities to Virú and the adjacent sierra, Guadalupito ceramics are uniformly made in the Moche style, however "provincial" they might have looked to an ancient potter from Moche Valley itself.

Another interesting feature of the ceramics relates to the total number of form types we were able to discern for Guadalupito as opposed to the earlier periods. The number of form types for the early periods in the sequence are 16 in Cayhuamarca, 20 in Vinzos, 29 in Early Suchimancillo, 39 in Late Suchimancillo, and 16 in Guadalupito. In other words, there is less ceramic diversity in the period of presumed occupation by a state than in any of the preceding periods, except Cayhuamarca. Kroeber (1944:126) remarked on the general paucity of basic form types "within which the Mochica expressed the endless individual variety of their ware," principally through painted decoration. Whether or not, in Santa, this is an indication of the imposition of a standardized set of form types is difficult to say. Certainly, however, Guadalupito is the first period in the Santa sequence when pottery seems completely like that of other nearby valleys, with little or no expression of local, or regional, traditions.

\section{DISCUSSION AND ANALYSIS}

The first two parts of this section of the paper discuss major demographic trends during the first six periods in the Lower Santa sequence and the probable rise of chiefdom societies in the pre-Guadalupito periods. Following this, quantitative analysis of maize-based carrying capacity is carried out, and then the implications of this analysis for the nature of intercluster relations, patterns of prestate warfare, and population pressure are examined in detail. Finally, the results of the analysis of cluster-level ceramic assemblages are briefly presented in view of the light they throw on the implications of the carrying capacity calculations. 


\section{Developmental Trends: Demographics}

Reviewing the settlement patterns and population estimates for the first six periods in the Lower Santa sequence, it seems clear that an orderly process of development occurred. During the Preceramic, when subsistence was limited primarily to a maritime focus and possibly huntinggathering and horticulture, the population was quite limited relative to the other periods. During the following Cayhuamarca Period, when irrigation agriculture had probably become the major source of food, the population had increased by $600 \%$ and was widely distributed in the Upper and Middle Valley sectors. The steeper gradients in these sectors would have required the least investment of labor in canal construction, and thus it is not surprising that the first major developments should take place here.

From the Vinzos Period on, the population continued to grow, first expanding in the Upper and Middle sectors and then into the Lower Valley sector. Finally, in Guadalupito Period the main subsistence-settlement focus had become the Middle and Lower sectors. As shown in Fig. 15 , the population growth curve for the periods leading to Guadalupito exhibits the classic exponential shape characteristic of most nuclear areas of the world after the introduction of agriculture (e.g., see Parsons 1974:103).

As for the sharp drop in population during Guadalupito Period, while we are likely never to know the precise set of circumstances that brought it about, it is highly intriguing that it should occur during the period when Santa probably became part of the Moche state. Without attempting to resolve the problem in greater detail here, several possible causes for the drop may be speculatively suggested. These include (1) high numbers of deaths as a result of warfare and conquest, (2) demographic adjustments to disruptions brought about by a forced change in subsistence-settlement focus, (3) demographic adjustments to a state-imposed system of tribute payments, namely, in the form of foodstuffs sent outside the valley, and (4) population resettlement outside Santa Valley along lines similar to the Inca institution of mitmaquna (cf. Rowe 1963:269-270). The first suggested cause seems least likely (cf. Divale and Harris 1976; Harris 1980:91), but any one of the other causes, or a combination thereof, seems possible.

\section{Developmental Trends: The Rise of Chiefdom Society}

As the population growth outlined above was occurring, it also seems clear that sociopolitical organization grew increasingly complex. The data summarized in Table 1 illustrate how, from the Preceramic through the end of Guadalupito Period, the hierarchy of site size and function grew 


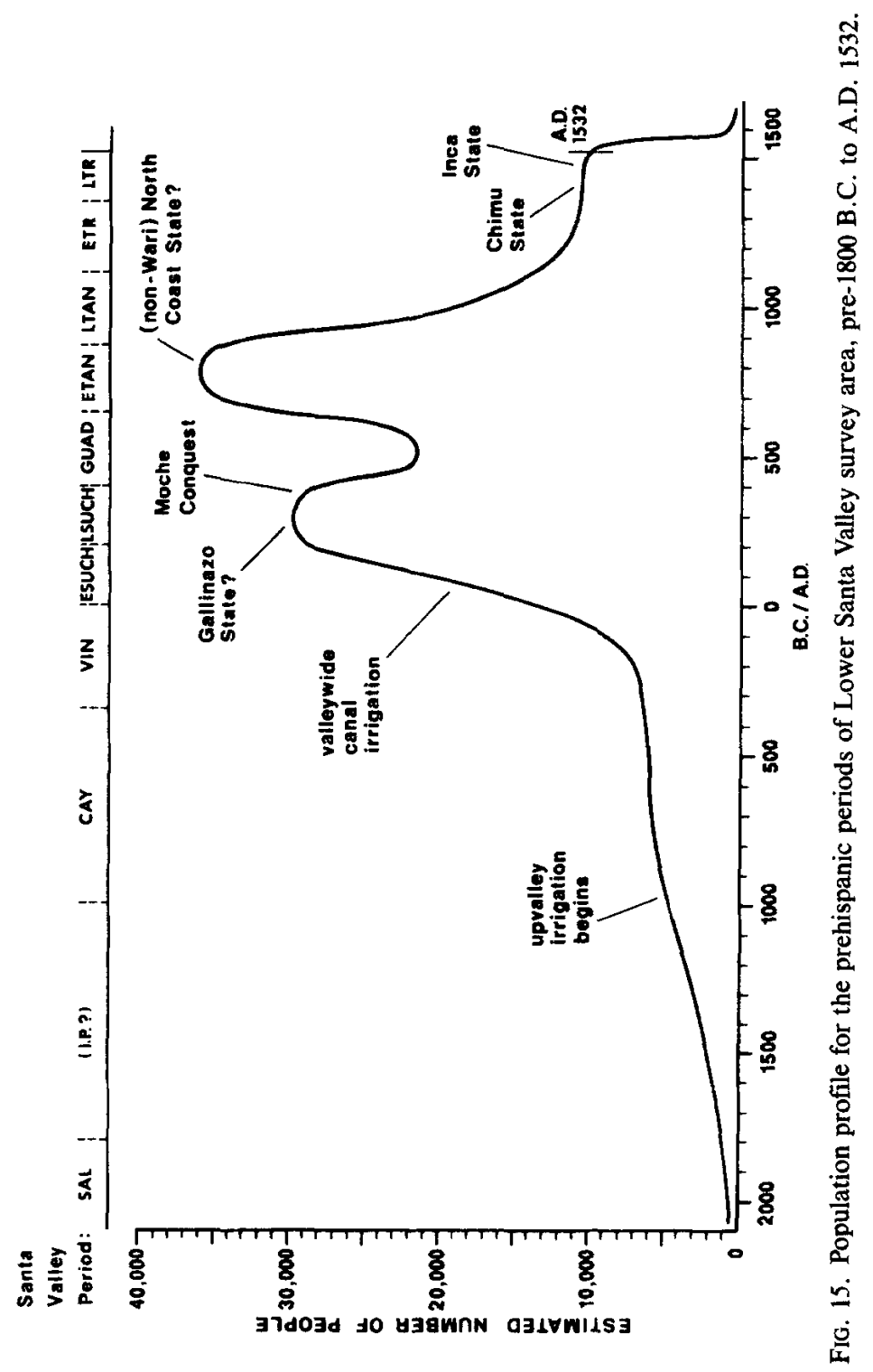


from only two levels to five levels. Since the evidence related to the state level of sociopolitical integration in Santa has been reviewed in detail in the preceding section, here I will limit the discussion to the development of the chiefdom societies that preceded state formation.

As argued earlier, the number of hierarchical levels, or tiers, in a given period is obviously a function of how one defines the population ranges of the settlement size categories. In preparing the data summarized in Table 1, however, an attempt was made to construct site size histograms using intervals that would result in "natural breaks" between major size groupings. In any case, as Table 1 shows, the number of hierarchical tiers is three for the Cayhuamarca and Vinzos Periods, and four for the Early Suchimancillo and Late Suchimancillo Periods. This points to the existence of certain basic structural similarities between the earlier two periods, on the one hand, and between the later two Suchimancillo periods, on the other. As I will indicate below, these similarities are also evident with regard to population size, settlement distributions, and supravillage productive activities. At the same time, it is clear that substantial differences exist between the earlier two and the later two periods, thus pointing to the probability that Early Suchimancillo Period represents the beginning of a radical developmental break in the pre-Guadalupito sequence.

The overall population size of the early agricultural groups in the Cayhuamarca and Vinzos Periods was roughly in a range of from 6000 to 8000 persons, which, as mentioned earlier, is substantially higher than the Preceramic population. Nevertheless, we are clearly still not dealing with groups of any appreciable size. For example, the maximum size of the majority of individual Cayhuamarca and Vinzos site clusters is only about 1000 persons (see Table 4, discussed later in this section). By the time of the Suchimancillo periods, the overall population size of the survey region is in a range of from 20,000 to 30,000 persons, or one-half to twothirds of the maximum population levels of the prehispanic sequence (ca. 36,000 persons in Early Tanguche Period). The size of the largest Early Suchimancillo settlement cluster is ca. 15,000 persons and that of the largest Late Suchimancillo cluster is ca. 19,000 persons.

With regard to the regional distribution of settlements, Cayhuamarca and Vinzos again stand apart from the later two periods. While settlement in the earlier two periods was essentially confined to the Upper and Middle Valley sectors, both the Suchimancillo periods are characterized by sites in the Upper, Middle, and Lower Valley sectors. Yet, as is clear from the settlement pattern maps, the primary population concentrations of all four of the pre-Guadalupito periods are in the Upper and Middle sectors of the valley. Nevertheless, even with regard to these two sectors, there is a marked change from the rather more dispersed distribution of 
sites in Cayhuamarca and Vinzos to an essentially continuous distribution in Early and Late Suchimancillo.

Considering the probability that longer irrigation canals had been constructed by the time of Early Suchimancillo, it seems likely that not only intervillage cooperation but also institutionalized supravillage coordination of public works had arisen by this period. However, since canals serving a number of villages were probably constructed as early as Cayhuamarca and Vinzos Periods, corporate labor projects may have had their beginning as early as the development of intensive irrigation agriculture in the Lower Santa Valley. Thus, while the two Suchimancillo periods clearly represent substantially more complex societies, using the criteria outlined earlier, a good case can be made for incipient chiefdom society from the time of Early Horizon on.

In sum, according to the criteria given for ranked societies, the larger clusters of both Early Suchimancillo and Late Suchimancillo probably represent developed chiefdom societies, while most, if not all, of the settlement clusters of Cayhuamarca and Vinzos represent an incipient stage of nonegalitarian society. An interesting question is whether Late Suchimancillo may qualify as a stratified, or state, society. The answer seems clearly to be a negative one, since Late Suchimancillo lacks many of the characteristics of state societies outlined earlier, including very large population size and larger monumental architecture. Indeed, examination of the data summarized in Tables 1 and 2 shows Late Suchimancillo to be essentially identical to the Early Suchimancillo Period. Thus, as argued earlier, it is not until the Guadalupito Period that one sees the sorts of qualitative changes that represent the rise of state society.

\section{Maize-based Carrying Capacity Analysis}

With regard to the clustering of sites in the pre-Guadalupito ceramic periods, and returning now to the assumptions of Carneiro's "coercive theory" outlined earlier, it appears probable that, from the start of irrigation agriculture in Cayhuamarca Period, the settlements of each cluster were focused at a supracommunity level on defensive and ceremonialcivic sites. Yet, it is also clear from the settlement pattern data that clusters decrease in number and increase in size through the periods preceding Guadalupito. Does this provide support for Carneiro's model? If it could be shown that the clusters in each period were autonomous, then it would be difficult to refute the model. However, the results of the analysis of maize-based carrying capacity suggest otherwise.

Estimating early agricultural carrying capacity. Table 3 summarizes in 


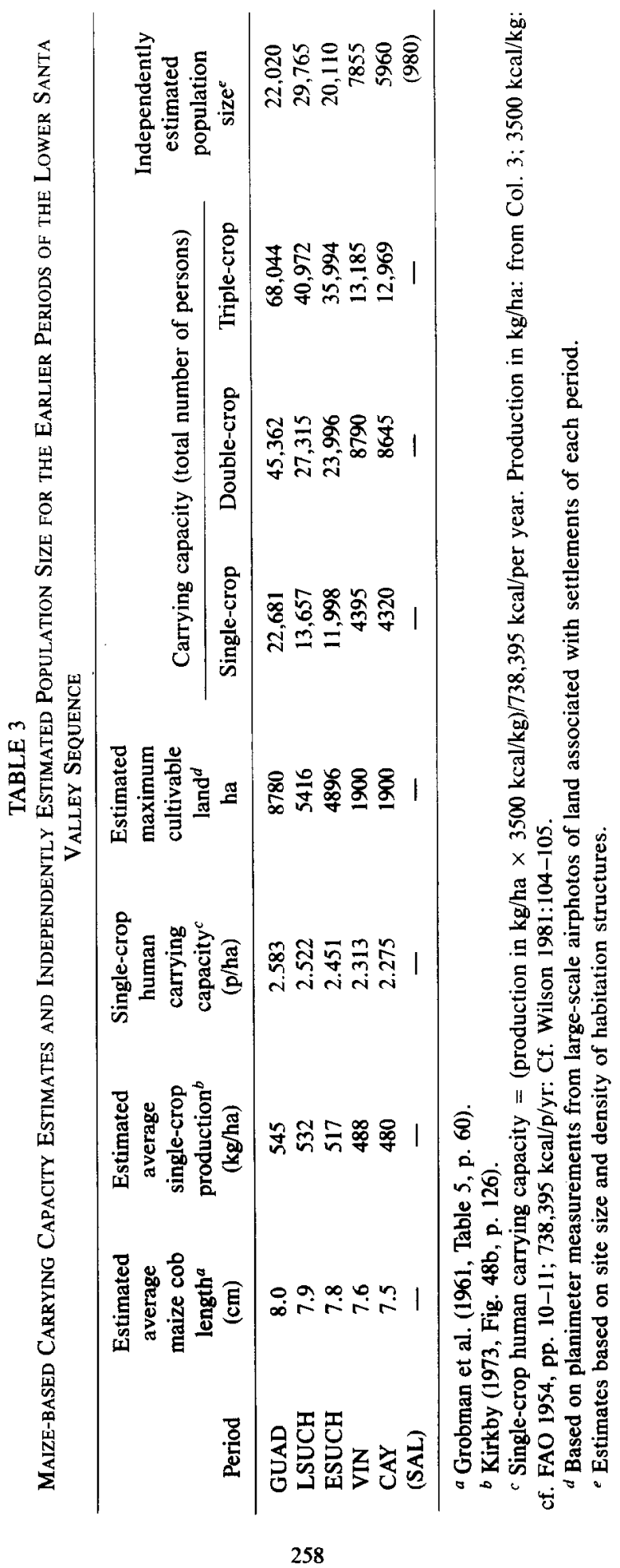


detail how the estimates of agricultural carrying capacity for the early ceramic periods were derived, based on (1) average maize cob lengths in centimeters, (2) maize production estimates in kilograms per hectare, (3) estimated single-crop human carrying capacity, and (4) estimates (made with a planimeter on large-scale airphoto tracings) of maximum hectares of irrigable land associated with the settlements of each period. The figures for estimated average cob length are from samples of whole cobs collected primarily at various South Coast sites for the periods in question (cf. Grobman et al. 1961, p. 60, Table 5). Average cob length estimates are available from some North Coast areas (cf. Bird 1978; Bird and Bird 1980), but they are of limited value for the present analysis since they are based partly on incomplete cobs. Nevertheless, while the estimates given for cob length in Table 3 must therefore be taken as tentative, the critical point to make here is that minor changes in cob length from period to period do not affect human carrying capacity nearly so much as do (1) total hectares of land estimated to be under cultivation, and (2) the nature of the water supply and number of crops possible per year.

Elsewhere (Wilson 1981:101-104), in comparing the early maritime and agricultural subsistence systems of coastal Peru, I have discussed at length the use of maize productivity as an index in calculating potential carrying capacity (see also Sanders and Price 1968:92-93), as well as the analytical procedures and assumptions involved in making such calculations. ${ }^{5}$ There, the objective of the analysis was to demonstrate that, even making the "best case" for maritime subsistence productivity and the "worst case" for agricultural productivity, the latter system could be shown to be substantially more productive than the former. By contrast, it may be said that the goal of the present analysis is more one of approximating a "real case" argument than of representing extremes.

Thus, as indicated in Table 3, single-crop human carrying capacity has been calculated using Food and Agricultural Organization estimates of caloric productivity of maize $(3500 \mathrm{kcal} / \mathrm{kg}$; see FAO 1954:10-11). Nevertheless, the estimated RDA (recommended daily allowance) of 2023

\footnotetext{
${ }^{5}$ It should be emphasized that using maize as an index of productivity does not at all imply that it alone was important in providing adequate nutrition. Indeed, it is probable that a combination of maize, beans, squash, peppers, and other cultigens was necessary in adequately meeting nutritional needs (cf. Sanders and Price 1968:89-94; FAO 1954, 1957a, 1957b). In addition, it is clear that in the Lower Santa region maritime resources made up a part of the diet of early agriculturalists from the Vinzos Period on, judging from the scattered marine shells present on many sites. However, it is unlikely that these resources provided anything more than a small percentage of the total dietary intake, given the limitations that characterized the maritime environment as well as early fishing technology (cf. Wilson 1981:107).
} 
$\mathrm{kcal} /$ person used in comparing the maritime and agricultural systems is appropriate for this analysis (cf. Wilson 1981:104; FAO 1957a:24-26, 4449). As shown in the equation in Table 3, the recommended yearly allowance of $738,395 \mathrm{kcal} / \mathrm{person}(2023 \mathrm{kcal} /$ person/day $\times 365$ days) is used in the denominator of the expression on the right for convenience in estimating the number of persons that could be supported by one maize crop from each hectare over a year's time.

It has been shown earlier in this paper that, because of the more than ample year-round supply of water, triple-cropping is possible in the Lower Santa Valley. Thus, as indicated in Table 3, it is appropriate to calculate potential maize-based carrying capacities for one, two, or three crops per year. The number of people that could be supported by these three cropping options may then be compared to the independently estimated population size (see discussion under Research Methods) for each period. Assuming one crop per year were inadequate-as is indeed the case for all pre-Guadalupito periods-then one may investigate possible combinations of hectarage under cultivation and cropping strategies that would be sufficient to support the estimated population.

Implications of the analysis. Wc are now in a position to analyze clusterby-cluster carrying capacity, and, in the process, suggest implications for Carneiro's theory. Summarizing Table 3, overall carrying capacity has been shown as a spatial and temporal variable dependent upon maize cob length, production in kilograms per hectare, cropping strategy, and total hectares of available land located throughout the settlement system of a given period (e.g., in Cayhuamarca or Vinzos Periods, this would include essentially all land in the Upper and Middle Valley).

However, in Table 4 the analysis includes only the land available to each cluster (assuming, for the moment, between-cluster conflict). Even with triple-cropping, the upper clusters (Clusters 1 and 2) in each of the pre-Guadalupito periods did not have nearly enough land to support the (independently estimated) population of the cluster. Clearly, the implication of the analysis is that the uppermost clusters relied from the start on land in clusters farther downvalley for subsistence. None of these clusters therefore could have been in competition with the others, and Carneiro's primary assumption that prestate conflict would involve withinvalley, or intercluster, warfare does not apply to the Lower Santa sequence.

Indeed, the results of the carrying capacity analysis can be taken a step farther in order to throw light on the issue of population pressure in the prestate periods. In the analysis summarized in Table 3, the procedure was to estimate single- and multicrop carrying capacities, and then compare these figures with the independently estimated population size. On the other hand, by essentially reversing the order of the analysis-i.e., 
TABLE 4

Intracluster Subsistence Analysis Showing (a) Maximum Amount of Irrigable Land and (b) Triple-Crop Human Carrying Capacity, Compared with (c) Estimated actual Population Size of Cluster ${ }^{a}$

\begin{tabular}{lllllll}
\hline & & \multicolumn{5}{c}{ Clusters } \\
\cline { 3 - 7 } Period & & \multicolumn{1}{c}{1} & \multicolumn{1}{c}{2} & \multicolumn{1}{c}{3} & 4 & 5 \\
\hline LSUCH & (a) & 381 & 1432 & 3603 & & \\
& (b) & 2880 & 10,835 & 27,260 & - & - \\
& (c) & 18,835 & 7645 & 3285 & & \\
ESUCH & (a) & 11 & 1890 & 2995 & & \\
& (b) & 80 & 13,900 & 22,020 & - & - \\
& (c) & 1070 & 15,030 & 4010 & & \\
VIN & (a) & 11 & 82 & 237 & 866 & 350 \\
& (b) & 75 & 570 & 1645 & 6110 & 2430 \\
& (c) & 1180 & 825 & 955 & 995 & 1310 \\
CAY & (a) & 11 & 368 & 380 & 275 & \\
& (b) & 75 & 2510 & 2590 & 1875 & - \\
& (c) & 950 & 3005 & 1040 & 950 & \\
\hline
\end{tabular}

a (a) measured in hectares; (b) persons; (c) persons.

by starting with the independently estimated population size, as well as agricultural carrying capacity and cultivable land available for each of the periods-one can suggest optimal cropping/clearing strategies and minimum land requirements for each period.

The results of this analysis are shown in Table 5. Thus, for example, in Cayhuamarca Period we may "begin" irrigation agriculture by postulating a double-cropping strategy on 1310 of the 1900 ha of irrigable land in the Upper and Middle Valley, a strategy sufficient to support the estimated population of 5960 persons. Although single-cropping 1900 ha would not be sufficient to support this many people, other less analytically "parsimonious" strategies involving combinations of double- and triple-cropping could also be suggested. Continuing through the periods, and following the general rule that it would be easier first to intensify on land already cleared (e.g., by changing from double- to triple-cropping), and second to clear more land, estimates can be made of how much intensification was required and how much land had to be added to the system to support the population of each period.

As shown in Table 5, all of the prestate periods, except Vinzos, probably required not only intensification of production, but also the addition of substantial amounts of land. Since the population was growing at a very small rate per annum, however, it may be assumed that an average 


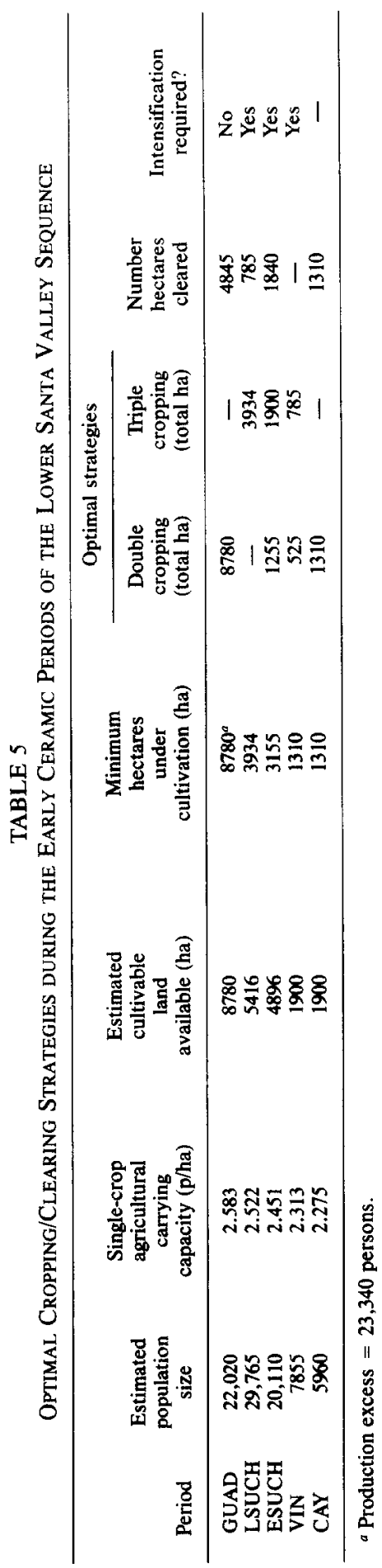


year's work in clearing more land would not have been excessively demanding. And, assuming that population pressure is a function of too many people and not enough land in areas adjacent to settlements, at no time in the prestate sequence can it be argued that pressure is "visible" in the system (cf. Cowgill 1975a, 1975b). In other words, within the constraints of total potentially cultivable land and the number of crops possible per year, no imbalance between population and land supply ever existed. It should also be noted, however, that this argument does not imply that population growth per se was not one of the "driving forces" in the prestate system.

A final intriguing aspect of the analysis summarized in Table 5 is the implications of the carrying capacity calculations for the nature of Guadalupito Period subsistence. As discussed earlier, the population size of the survey area during this period appears to have been only about twothirds that of the preceding Late Suchimancillo Period. Yet, as is made clear in Fig. 12 (see also Fig. 13), the location of sites throughout the Santa and Lacramarca areas of the Lower Valley sector, as well as in most of the Middle Valley sector, suggests that substantially more land was being farmed than in the preceding period.

Indeed, support for the assertion that something approaching the maximum amount of land (8780 ha) associated with Guadalupito settlements was now under cultivation comes from the opening up of the mouth of Quebrada de Lacramarca during the period of Moche occupation. It seems unlikely this would have been necessary if all or nearly all of the land associated with sites in the Santa Valley were not already under cultivation. For this reason, and for purposes of illustration, 8780 ha have been taken in Table 5 as the amount of land being farmed during Guadalupito Period. Interestingly enough, just single-cropping this many hectares would have supported more than adequately the estimated population of 22,020 persons $(8780$ ha $\times 2.583$ persons $/$ ha $=22,680$ persons $)$. Thus, the advantages of Santa Valley to the overall subsistence/tribute system of a conquest state become obvious when one calculates the production excess-as measured in human carrying capacity-resulting from the postulated double-cropping strategy shown in Table 5: 8780 ha $\times$ 2.583 persons $/$ ha $\times 2$ crops $/$ year $=45,360$ persons supported over a year's time, or an excess number of 23,340 persons beyond the immediate subsistence needs of the local population.

\section{Analysis of Ceramic Assemblages at the Cluster Level}

Returning to the nature of relations between clusters in a period, a final analytical procedure followed was to compare cluster-level ceramic assemblages between contiguous clusters using the Brainerd-Robinson 
coefficient of agreement (cf. Doran and Hodson 1975:139). The results of the analysis (shown in Table 6) suggest strong similarities between Clusters 1 and 2 in the Vinzos and Late Suchimancillo Periods, as well as between Clusters 2 and 3 in the Cayhuamarca, Vinzos, and Early Suchimancillo Periods. This lends support to the implications of the carrying capacity analysis, although I cannot yet explain the lower values shown in some cells of the table. In any case, in sociopolitical and economic terms, the minimal set of cooperating (or neutral) clusters in each of the prestate ceramic periods was demographically so superior to the remaining cluster(s) farther downvalley that it is difficult to imagine any sort of within-valley conflict.

\section{SUMMARY: A DEVELOPMENTAL MODEL}

\section{Implications for the Coercive Theory}

As outlined earlier in this paper, the "coercive theory" of state origins is based on the central assertion that, within a sharply circumscribed environment, population growth brought about by the introduction of irrigation agriculture would lead inevitably to land shortage and locallevel conflict. State formation at the regional, or intravalley, level would take place as the militaristic and political result of (1) increasing betweenvillage and between-group warfare, and (2) defeat of weaker groups, and their incorporation into ever larger, victorious polities. It has been asserted that included among the testable assumptions of the theory are (1)

TABLE 6

InTERCluster ANalysis: Comparison of Cluster-Level Ceramic ASSEmblages Using BRAINERD-ROBINSON INDEX OF SIMILARITY ${ }^{a}$

\begin{tabular}{lrccc}
\hline & \multicolumn{4}{c}{ Clusters } \\
\cline { 2 - 5 } Period & $1-2$ & $2-3$ & $3-4$ & $4-5$ \\
\hline$\quad$ Late & & & \\
$\quad$ Suchimancillo & 146.3 & 82.7 & - & - \\
$\quad \begin{array}{l}\text { Early } \\
\quad \text { Suchimancillo }\end{array}$ & 58.2 & 111.4 & - & - \\
$\quad$ Vinzos $^{b}$ & 120.9 & 107.9 & 69.3 & 81.5 \\
$\quad$ Cayhuamarca & 76.5 & 147.4 & 67.9 & - \\
\hline
\end{tabular}

a Analysis was carried out using a PET $\mathbf{4 0 1 6}$ microcomputer and a program written in BASIC by the author.

${ }^{b}$ Analysis excludes Vinzos Cluster 6 from which no collections were made. 
an initial stage of autonomous agricultural villages, (2) population pressure, and (3) intersite and intergroup conflict. It has also been suggested that, given a dichotomous theoretical choice between a voluntaristic model and the coercive model, the latter approach has obvious attractions.

Nevertheless, the analysis carried out in the preceding section suggests that the above assumptions of the coercive model cannot be supported by the data for the early periods in the Lower Santa Valley sequence. First of all, there is no support for the notion of an initial stage of completely autonomous villages. The presence of settlement clustering from the time of the earliest appearance of irrigation agriculture, and the internal composition of the clusters themselves, make it likely that the sites of each cluster were focused at a supracommunity level on ceremonialcivic and defensive sites. And local-level subsistence activities may have involved at least a modicum of cooperative and coordinated behavior as well.

Second, the analysis of maize-based carrying capacity suggests that, because of the relatively scarce supply of land in the Upper Valley sector, the large populations in settlement clusters of this area had to have access to sections of the valley floor downriver adjacent to other clusters. Third, taken in conjunction with the analysis of optimal cropping/clearing strategies, the comparison of independently estimated population figures to the carrying capacity of land adjacent to settlements does not support the assertion of population pressure.

Given the clear indications of the analysis of settlement patterns and maize-based carrying capacity that relations between sites, as well as between clusters, were peaceful, it must be concluded that warfare in the Lower Santa Valley during the prestate ceramic periods involved raiding from outside the region. Indeed, this conclusion is strongly supported by the widespread distribution of fortresses throughout the lower, more exposed sectors of the valley in all of the pre-Guadalupito ceramic periods. And, as argued earlier, the inescapable implication of the analysis of the archaeological data is that conflict was occurring between Santa and other coastal valleys, and not between Santa and the adjacent sierra. ${ }^{6}$ It may be further suggested that the threat of external raids may provide an explanation of the clustered settlement pattern, especially in the earlier prestate periods. Thus, the clusters of Cayhuamarca and Vinzos Periods may reflect the need to group around suitable defensive sites. The widespread distribution of the clusters, in turn, may relate to the need to

\footnotetext{
${ }^{6}$ No argument is being made that warfare between coastal valleys was continuous. If ceramic similarities between valleys may be taken as an indication that relations at times involved some sort of economic exchange, then we may also assume that intervalley relations at times were characterized by peace as well as war.
} 
effectively farm most of the Upper and Middle Valley floor to sustain the large and growing population.

To return to the dichotomous theoretical choices posed by Carneiro (1970:733-734), it must not be assumed that refutation of the "coercive theory" necessarily implies that the only alternative is the voluntaristic approach such as that taken by Wittfogel with his "hydraulic hypothesis" (cf. Wittfogel 1956, 1960). Rather, the analysis carried out in this paper suggests another approach to understanding coastal Peruvian state origins, one that relies neither on a voluntaristic model nor on the coercive one. This other approach, as mentioned earlier, involves a model of multivariate causality.

\section{A Multivariate Developmental Model}

The multivariate model shown in Fig. 16 summarizes the principal arguments made about the origin and development of complex society in the Lower Santa Valley, and speculatively suggests a few additional components in the prestate system that are implied by the analysis carried out in this paper. Although the model may be viewed as describing generally the nature of the pre-Guadalupito periods, it is intended specifically to apply to the earlier periods of incipient agriculture. Thus, it focuses more on the initial set of factors and stresses that help explain the origin of ranked society than on specifying every component implied by the analysis of the more complex, later systems of Early and Late Suchimancillo Periods. For example, the reasonably clear evidence for trade between the Lower Santa area and the adjacent sierra, while potentially an important part of the overall processes leading to stratified society, is not considered in the model.

As shown in Fig. 16, the components of the developmental model are organized under (1) socioenvironmental factors, (2) socioenvironmental stresses, and (3) behavioral adaptations. Distinguishing between specific socioenvironmental factors and stresses is viewed here as a reasonable means of separating out those aspects of the physical and sucial environment that seem to have made certain developments possible (i.e., factors), and those aspects that may have been more directly causal (i.e., stresses) in selecting for specific behavioral adaptations. Among the socioenvironmental factors that have been discussed for the Lower Santa area are (1) year-round water supply, (2) the possibility of year-round cropping, and (3) improved varieties of cultigens. It should be clear that none of these suggested factors implies that a deterministic model of development is being invoked. The prehispanic inhabitants of Santa could choose whether or not to farm, as well as how many crops to plant, at 


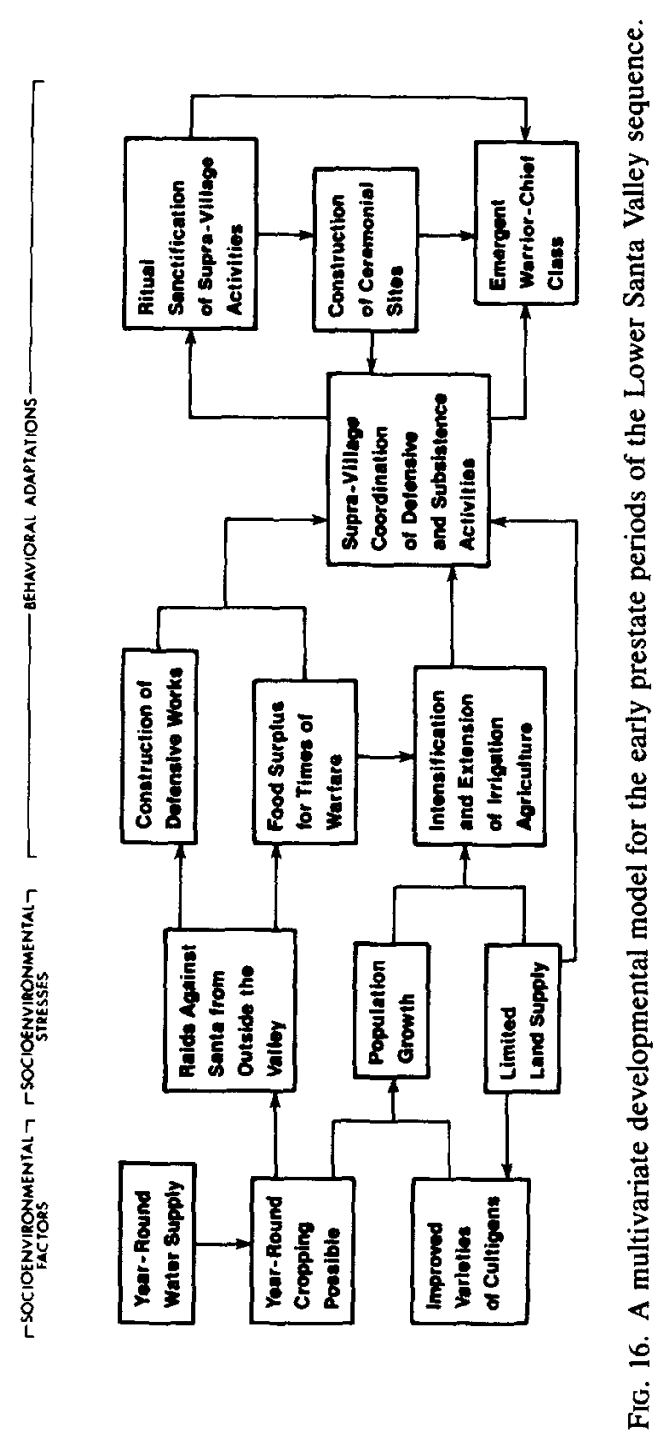


least in the early stages. But once the population began to grow, and agriculture became more intensive and extensive, it is equally clear that there was no going back to the relatively limited maritime subsistencesettlement system of the Preceramic. Having thus reached a point of no return, the incipient agriculturalists of the Lower Santa Valley essentially had become "locked into" the new subsistence-settlement focus.

Among the socioenvironmental stresses that become relevant at this point are (1) raids against Santa from outside the valley, (2) population growth, and (3) limited land supply. As indicated in Fig. 16, an underlying reason for external raiding may be that Santa, unlike any other nearby valley on the North Coast, has a year-round water supply. Thus, unlike any other nearby valley, crops would potentially be available for harvesting at any time of the year. If we suppose that the people of any nearby valley with only a seasonal water supply were suffering shortages of food brought about, for example, by inadequate storage practices, then the attraction of Santa as a focus of raids becomes obvious (I am assuming here that the causes of war must be sought in specific socioenvironmental factors, and not in the notion of "innate human aggression"; cf. Harris 1980:90-92). Moreover, as suggested in the model, a possible adaptation to external raiding in the Lower Santa area would be the storage of food to tide people over periods of strife.

Aside from the creation of food surpluses as response to warfare, one of the principal components of the model viewed as promoting supracommunity organization is the need for coordination of some aspects of the subsistence system. With a more than ample supply of water year-round and no need for controlling water usage, it seems possible that the overall scarcity and unequal distribution of land together could have constituted a socioenvironmental stress that promoted managerial functions. Such higher-order controls over subsistence and land usage in Santa are suggested principally by the presence of higher numbers of people in the Upper Valley sector than could be supported by the available land supply.

Nevertheless, the best evidence we have for a socioenvironmental stress promoting the rise of supracommunity organization is the widespread presence of defensive sites in the prestate ceramic periods. Indeed, when one views the settlement pattern of these periods, the Lower Santa takes on the appearance of a "garrison valley." Warfare, specifically in the form of raids from outside the region, is therefore clearly an important factor creating the socioenvironmental context for the rise of complex society. But it cannot be overemphasized that there is a vast difference between arguing for external warfare as an adaptive milieu promoting sociocultural complexity, and arguing that internecine aggression and coercion brought about the rise of complex society. The first of these views is that taken in this paper, as suggested by the analysis of the Lower 
Santa Valley data. The second view is, of course, that taken by the "coercive theory."

Thus, the Santa data suggest that coercion becomes relevant only at the time of the development of the multivalley state. Indeed, if we assume it has been clearly demonstrated that prestate groups in Santa Valley went to a lot of trouble to keep from being overcome by outside raiders, then certainly they had to be "coerced" into becoming part of the Moche state. In this sense, the processes bringing about the rise of multivalley states are theoretically more straightforward and direct than are those which led to the rise of complex society at the regional level.

\section{Implications for Other Coastal Valleys}

A final problem worth considering is the extent to which the developmental model suggested by the Santa data applies to other nearby coastal valleys. In other words, are the powerful integrative forces that seem to operate from the start of agriculture in the Lower Santa characteristic only of that valley, and therefore unique on the North Coast? Another way of phrasing this question is to ask whether the "coercive theory" may indeed apply to some of the other valleys. Obviously, satisfactory answers to the problem posed here will only come with further systematic investigation at the regional level, but some tentative predictions can nevertheless be made.

In the first place, it is clear that the developmental models for valleys such as Nepeña and Virú would include different socioenvironmental factors and stresses than the model for Santa. As is the case in other nearby valleys, Virú and Nepeña are limited more by seasonality and scarcity of water supply than by scarcity of land. But, due to the lack of systematic, regionally oriented research in these valleys, it remains an open question whether the problems of water allocation would promote valley-wide integration. In any case, the principal issue here is not prediction of specific integrative factors, but whether or not Carneiro's model applies elsewhere. And, if we begin by assuming that the threat of external warfare promoted an organized response in the Lower Santa, as argued in this paper, then it may follow that the groups attacking Santa were organized to carry out that warfare. What I am suggesting is that it is difficult, if not impossible, to imagine that valleys mired in aggressive, internecine fighting and "coercion" could ever pose a serious threat to other groups of incipient agriculturalists who had organized to the point of developing a defensive system capable of resisting external attacks. Clearly, we have not answered the question of what factors promoted early integration in other valleys, but, given the Santa data, it seems unlikely that the "coercive theory" applies anywhere else. 


\section{CONCLUSIONS}

The underlying theme of this paper may be said to be an implicit plea for applying a systematic and comprehensive regional approach as an integral part of studies of the coastal Peruvian archaeological record. Considering the historical fact that the use of regional settlement pattern data as a means of understanding prehistoric sociocultural development began with the 1946 Virú Valley Project, it is surprising how little it has been applied to the study of coastal valleys since that time. And, considering how much more sophisticated settlement pattern methods, as well as theories about the rise of complex society, have become since that time, it is equally surprising that few of these advances have been incorporated in coastal research. Yet, it is clear that the Peruvian coast has much to offer, not only in terms of the remarkable surface preservation of even the earliest remains, but also in contributing to attempts to construct cross-culturally valid theories of the origins and development of complex society.

Indeed, it is likely that there are few other areas in the world where the ecological approach to understanding prehistoric cultural development can be more effectively applied. To provide just one example of this, as discussed earlier in this paper, one of the more clearcut procedures in the Lower Santa research was defining survey boundaries so as to include meaningful environmental and demographic units. Although the lines between Santa and other valleys become rather blurred in the later periods when roads and sites extend out across the desert, the desert itself (as well as the ocean, the narrow upper reaches of the valley, and the steep desert slopes of the western flank of the cordillera) provides clear boundaries enclosing human populations. The same sharp circumscription is, of course, characteristic of all valleys in the vicinity of Santa mentioned in this paper. And, while some of these oasis valleys were clearly more important (e.g., Moche) than others (e.g., Santa), each has much to offer in showing how the people of one coastal microcosm adapted to the problem of living in a circumscribed environment.

Another major theme of this paper, and one that I have attempted to carry out in the spirit of the methodological precedents set by the members of the Virú Valley Project, is to lay out as explicitly as possible the main aspects of the research methods used. At least one justification for specifying these methods is to make it possible for other researchers to adequately assess the strengths and weaknesses of the approach taken. Clearly, some of the methods used in analyzing the Lower Santa data are in an incipient stage of development. One example of this is the approach taken in estimating population figures for sites with varying densities of habitation structures. It seems likely that ongoing attempts to estimate 
population will become more sophisticated, especially as detailed studies and maps are made of more sites of various sizes and functions. Yet, to my knowledge, no explicit procedures for such a method, as applied specifically to the coast of Peru, have been set forth in the literature prior to this time. Thus, although I am reasonably comfortable with the approach taken in estimating relative demographic potential and change, it is also to be expected that much methodological improvement can take place.

A final major theme has been to use the systematically gathered regional settlement data from the Lower Santa area not only to outline principal aspects of a sequence leading to sociocultural complexity and state formation, but also to critically examine a model purporting to specify the major causal factors and characteristics of that sequence. As we have seen, the origins and development of complex society in the Santa area probably involved a complex set of mutual causative relationships between various components in the early agricultural system. That these relationships were more complex than outlined here seems likely. Nonetheless, as indicated in the developmental model proposed in this paper, it seems clear that warfare was at least one of the major socioenvironmental stresses promoting the rise of complex society, but not at all in the manner predicted by the "coercive theory."

That this warfare probably occurred between groups living in different valleys located at some distance apart, and that it was more or less continual, seem hardly surprising. Warfare between groups "foreign" to each other has been known to occur with some frequency in more recent times. However, that it did not occur between neighboring groups of intensive irrigation agriculturalists-groups with little to gain and much to lose by 1000 years of internecine conflict and coercion-seems a small vote for reason in the face of some recent attempts to impute innate aggression to the species.

\section{ACKNOWLEDGMENTS}

The research upon which this paper is based was supported by grants from the National Science Foundation, the Wenner-Gren Foundation for Anthropological Research, the Center for Field Research/Earthwatch, and HEW Fulbright-Hays Overseas Doctoral Research Program. Fieldwork in Peru was carried out under the auspices of the Universidad Nacional de San Marcos and the University of Michigan, with a permit issued by the Instituto Nacional de Cultura. Among numerous colleagues who have provided help and encouragement during the project, I especially thank Donald Collier, Robert Feldman, Kent Flannery, Roberto Frisancho, Richard Keatinge, Ramiro Matos, Craig Morris, Michael Moseley, Jeffrey Parsons, Shelia Pozorski, Thomas Pozorski, Donald Proulx, Douglas Sharon, Henry Wright, and Delfin Zúniga. Whatever success this project has achieved is due in large part to the able efforts of a number of field assistants from the U.S., Peru, and Argentina; they include Benigno Araico, Stephen Benjamin, Manuel Chávez, Kathy Cleland, Connie Cochran, 
Kenneth Fain, Hernán González, Douglas Lambert, Christopher Libby, Víctor Llacas Díaz, Ethan Mascoop, María Mercedes Herrera, Julia Middleton, Fidelia Notman, Mark Notman, Manuel Roncal Díaz, Víctor Manuel Roncal, Brian Rosencrantz, Allan Schollenberger, Glen Wilson, Joan Zofnass, and Paul Zofnass. To my wife, Diana, and son, Jonathan, I owe an incalculable debt, both for their support and for unfailing patience with the long-term process of completing a research project. Jeffrey Parsons, Richard Schaedel, and Diana Wilson have read and constructively critiqued earlier versions of this paper, for which I thank them. They and the anonymous reviewers have aided me considerably in attempting to focus more sharply and defend the arguments presented. Responsibility for the views expressed and for any factual errors is, of course, mine alone.

\section{REFERENCES CITED}

Adams, Robert McC.

1962 Agriculture and urban life in early southwestern Iran. Science 136:109-122.

1965 Land behind Baghdad: a history of settlement on the Diyala Plains. Univ. of Chicago Press, Chicago.

1966 The evolution of urban society: early Mesopotamia and prehispanic Mexico. Aldine, Chicago.

1970 The study of ancient Mesopotamian settlement patterns and the problem of urban origins. Sumer 25:111-124.

1981 Heartland of cities: surveys of ancient settlement and land use in the central floodplain of the Euphrates. Univ. of Chicago Press, Chicago.

Adams, Robert McC., and Hans J. Nissen

1972 The Uruk countryside: the natural setting of urban societies. Univ. of Chicago Press, Chicago.

Ashmore, Wendy (editor)

1981 Lowland Maya settlement patterns. Univ. of New Mexico Press, Albuquerque. Bankes, G. H. A.

1972 Settlement patterns in the lower Moche Valley, north Peru, with special reference to the Early Horizon and Early Intermediate Periods. In Man, settlement, and urbanism, edited by P. J. Ucko, R. Tringham, and G. W. Dimbleby, pp. 903-908. Duckworth, London.

Bennett, Wendell C.

1944 The north highlands of Peru: excavations in the Callejón de Huaylas and at Chavín de Huantar. Anthropological Papers of the American Museum of Natural History, Vol. 39, Part 1.

1950 The Gallinazo Group, Virú Valley, Peru. Yale University Publications in Anthropology, 43.

Benson, Elizabeth P.

1972 The Mochica: a culture of Peru. Praeger, New York.

Bird, Robert McK.

1978 Archaeological maize from Peru. Maize Genetics Cooperation News Letter 52: 90-92.

Bird, Robert McK., and Junius B. Bird

1980 Gallinazo maize from the Chicama Valley, Peru. American Antiquity 45: 325-332.

Blanton, Richard E., Stephen Kowalewski, Gary Feinman, and Jill Appel

1982 Monte Alban's hinterland, part 1: the prehistoric settlement patterns of the central and southern parts of the Valley of Oaxaca, Mexico. Memoirs of the Museum of Anthropology, 15. University of Michigan, Ann Arbor. 
Bonavía, Duccio

1974 Ricchata quellccani: pinturas murales prehispánicas. Editorial Ausonia, Lima, Peru.

Bullard, W. R., Jr.

1960 Maya settlement patterns in northeast Petén, Guatemala. American Antiquity 25:355-372.

Carneiro, Robert L.

1961 Slash and burn among the Kuikuru and its implications for cultural development in the Amazon Basin. In The evolution of horticultural systems in native South America: causes and consequences, edited by Johannes Wilbert, pp. 47-68. Sociedad de Ciencias Naturales La Salle, Caracas.

1970 A theory of the origin of the state. Science 169:733-738.

Collier, Donald

1955 Cultural chronology and change as reflected in the ceramics of the Virú Valley, Peru. Fieldiana: anthropology, 43. Chicago Natural History Museum.

1960 Archaeological investigations in the Casma Valley, Peru. Akten des 34. Internationalen Amerikanistenkongresses, pp. 411-417. Vienna.

Cowgill, George L.

1975a On causes and consequences of ancient and modern population changes. American Anthropologist 77:505-525.

1975b Population pressure as a non-explanation. American Antiquity 40:127-131.

Divale, William Tulio, and Marvin Harris

1976 Population, warfare, and the male supremicist complex. American Anthropologist 78:521-538.

Donnan, Christopher B.

1973 Moche occupation of the Santa Valley, Peru. University of California Publications in Anthropology, 8.

1976 Moche art and iconography. UCLA Latin American Center, University of California, Los Angeles.

1978 Moche art of Peru: Pre-columbian symbolic communication. UCLA Latin American Center, University of California, Los Angeles.

Donnan, Christopher B., and Carol J. Mackey

1978 Ancient burial patterns of the Moche Valley, Peru. Univ. of Texas Press, Austin.

Doran, J. E., and F. R. Hodson

1975 Mathematics and computers in archaeology. Harvard Univ. Press, Cambridge. Earle, Timothy K.

1972 Lurín Valley, Peru: Early Intermediate Period settlement development. American Antiquity 37:467-477.

FAO (Food and Agriculture Organization of the United Nations)

1954 Food composition tables: minerals and vitamins. FAO Nutritional Studies, 11. Rome.

1957a Calorie requirements. Report of the Second Committee on Calorie Requirements. FAO Nutritional Studies, 15. Rome.

1957b Protein requirements. Report of the FAO Committee. FAO Nutritional Studies, 16. Rome.

Flannery, Kent V.

1972 The cultural evolution of civilizations. Annual Review of Ecology and Systematics 3:399-426.

Flannery, Kent V. (editor)

1976 The early mesoamerican village. Academic Press, New York.

Ford, James Alfred, and Gordon R. Willey 
1949 Surface survey of the Virú Valley, Peru. Anthropological Papers of the American Museum of Natural History, 43, Part 1, pp. 5-89.

Grobman, Alexander, Wilfredo Salhuana, and Ricardo Sevilla with Paul C. Mangelsdorf

1961 Races of maize in Peru: their origins, evolution and classification. National Academy of Sciences, Washington, National Research Council Publication, 915.

Hardesty, Donald L.

1977 Ecological anthropology. Wiley, New York.

Harris, Marvin

1975 Cows, pigs, wars and witches: the riddles of culture. Vintage, New York.

1977 Cannibals and kings: the origins of cultures. Vintage, New York.

1980 Cultural materialism: the struggle for a science of culture. Vintage, New York.

Hastings, C. Mansfield, and M. Edward Moseley

1975 The adobes of Huaca del Sol and Huaca de la Luna. American Antiquity 40: 196-203.

Haviland, William A.

1972 Family size, prehistoric population estimates, and the ancient Maya. American Antiquity 37:135-139.

Jochim, Michael A.

1981 Strategies for survival: cultural behavior in an ecological context. Academic Press, New York.

Johnson, Gregory Alan

1973 Local exchange and early state development in southwestern Iran. Anthropological Papers, Museum of Anthropology, 51. University of Michigan, Ann Arbor.

Kirkby, Anne V. T.

1973 The use of land and water resources in the past and present Valley of Oaxaca, Mexico. Memoirs of the Museum of Anthropology, 5. University of Michigan, Ann Arbor.

Kroeber, A. L.

1944 Peruvian archaeology in 1942. Viking Fund Publications in Anthropology, 4. New York.

Larco Hoyle, Rafael

1963 La cultura santa. Lit. Valverde, Lima.

Lumbreras, Luis G.

1974 The peoples and cultures of ancient Peru, translated from the Spanish by Betty J. Meggers. Smithsonian Institution, Washington, D.C.

Lynch, Thomas F.

1980 Guitarrero Cave: early man in the Andes. Academic Press, New York.

Moseley, Michael E.

1975a Prehistoric principles of labor organization in the Moche Valley, Peru. American Antiquity 40:191-196.

1975b The maritime foundations of Andean civilization. Cummings, Menlo Park, Calif.

Naroll, Raoul

1962 Floor area and settlement population. American Antiquity 27:587-588.

ONERN (Oficina Nacional de Evaluación de Recursos Naturales)

1972 Inventario, evaluación y uso racional de los recursos naturales de la costa: cuencas de los ríos Santa, Lacramarca y Nepeña. 3 vols. ONERN, Lima.

Parsons, Jeffrey R.

1971 Prehistoric settlement patterns in the Texcoco region, Mexico. Memoirs of the Museum of Anthropology, 3. University of Michigan, Ann Arbor. 
1974 The development of a prehistoric complex society: a regional perspective from the Valley of Mexico. Journal of Field Archaeology 1:81-108.

Parsons, Jeffrey R., Elizabeth Brumfiel, Mary H. Parsons, and David J. Wilson

1982 Prehispanic settlement patterns in the southern Valley of Mexico: the ChalcoXochimilco region. Memoirs of the Museum of Anthropology, 14. University of Michigan, Ann Arbor.

Patterson, Thomas C.

1971 Central Peru: its population and economy. Archaeology 24:316-321.

Patterson, Thomas Carl, and Edward P. Lanning

1964 Changing settlement patterns on the central Peruvian coast. Nawpa Pacha 2: 113-123.

Peebles, Christopher S., and Susan M. Kus

1977 Some archaeological correlates of ranked societies. American Antiquity 42: $421-448$.

Price, Barbara J.

1982 Cultural materialism: a theoretical review. American Antiquity 47:709-741.

Proulx, Donald A.

1968 An archaeological survey of the Nepeña Valley, Peru. Research Reports, Department of Anthropology, 2. University of Massachusetts, Amherst.

1973 Archaeological investigations in the Nepeña Valley, Peru. Research Reports, Department of Anthropology, 13. University of Massachusetts, Amherst.

Reiche, María

1968a Giant ground-drawings on the Peruvian desert. Verhandlungen des XXXVIII Internationalen Amerikanistenkongresses, Vol. 1, pp. 379-384. StuttgartMuenchen.

1968b Mystery on the desert. Heinrich Fink, Stuttgart.

Robinson, David A.

1971 Peru in 4 dimensions. Blaine Ethridge, Detroit.

Rowe, John Howland

1963 Inca culture at the time of the Spanish conquest. In Handbook of South American Indians, edited by Julian H. Steward, Vol. 2, pp. 183-330. Cooper Square, New York.

Sanders, William T., and Barbara J. Price

1968 Mesoamerica: the evolution of a civilization. Random House, New York.

Sanders, William T., Jeffrey R. Parsons, and Robert S. Santley

1979 The Basin of Mexico: ecological processes in the evolution of a civilization. Academic Press, New York.

Savoy, Gene

1970 Antisuyo. Simon \& Schuster, New York.

Schaedel, Richard P.

1951 Mochica murals at Pañamarca. Archaeology 4:145-154.

Service, Elman R.

1975 Origins of the state and civilization: the process of cultural evolution. Norton, New York.

Shippee, Robert

1932 The "Great Wall of Peru" and other aerial photographic studies by the ShippeeJohnson Peruvian expedition. The Geographical Review 22:1-29.

Strong, William Duncan, and Clifford Evans, Jr.

1952 Cultural stratigraphy in the Viru Valley, northern Peru: the Formative and Florescent Epochs. Columbia Univ. Press, New York. 
Tello, Julio C.

1956 Arqueología del Valle de Casma. Editorial San Marcos, Lima.

Thompson, Donald E.

1962 Formative period architecture in the Casma Valley, Peru. XXXV Congreso Internacional de Americanistas, Actas y Memorias, Vol. 1, pp. 205-212. Mexico, D.F.

1964 Postclassic innovations in architecture and settlement patterns in the Casma Valley, Peru. Southwestern Journal of Anthropology 20:91-105.

Topic, John R., and Theresa Lange Topic

1978 Prehistoric fortification systems of northern Peru. Current Anthropology 19: 618-619.

Webb, M. C.

1968 Carneiro's hypothesis of limited land resources and the origins of the state: a Latin Americanist's approach to an old problem. South Eastern Latin Americanist 12:1-8.

Webster, David

1975 Warfare and the evolution of the state: a reconsideration. American Antiquity 40:464-470.

Wegner, Steven A.

1981 Identifying Recuaydom: an expanded ceramic inventory for identifying Recuay settlement sites. Unpublished paper presented at the 46th Annual Meeting of

Willey, Gordon R. the Society for American Archaeology, April 30-May 2, San Diego.

1953 Prehistoric settlement patterns in the Virú Valley, Peru. Smithsonian Institution, Bureau of American Ethnology Bulletin 155. U.S. Govt. Printing Office, Washington, D.C.

Willey, G. R., W. R. Bullard, Jr., J. B. Glass, and J. C. Gifford

1965 Prehistoric Maya settlements in the Belize Valley. Papers of the Peabody Museum, 54. Harvard Univ. Press, Cambridge.

Wilson, David J.

1981 Of maize and men: a critique of the maritime hypothesis of state origins on the coast of Peru. American Anthropologist 83:93-120.

Wittfogel, Karl A.

1956 The hydraulic civilizations. In Man's role in changing the face of the earth, edited by W. Thomas, pp. 152-164. Univ. of Chicago Press, Chicago.

1960 Developmental aspects of hydraulic societies. In Irrigation civilizations: a comparative study. Pan American Union, Washington, D.C.

Wright, Henry T.

1978 Toward an explanation of the origin of the state. In Origins of the state: the anthropology of political evolution, edited by Ronald Cohen and Elman R. Service, pp. 49-68. Institute for the Study of Human Issues, Philadelphia.

Wright, Henry T., and Gregory A. Johnson

1975 Population, exchange, and early state formation in southwestern Iran. American Anthropologist 77:267-289. 